OAK RIDGE NATIONAL LABORATORY

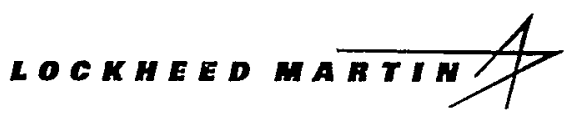

\begin{abstract}
An Econometric Analysis of the Elasticity of Vehicle Travel with Respect to Fuel Cost per Mile Using RTEC Survey Data
\end{abstract}

David L. Greene

James Kahn

Robert Gibson 
This report has been reproduced from the best available copy.

Reports are available to the public from the following source.

National Technical Information Service

5285 Port Royal Road

Springfield, VA 22161

Telephone 703-605-6000 (1-800-553-6847)

TDD 703-487-4639

Fax 703-605-6900

E-mail orders@ntis.fedworld.gov

Web site http://www.ntis.gov/ordering.htm

Reports are available to U.S. Department of Energy (DOE) employees, DOE contractors, Energy Technology Data Exchange (ETDE) representatives, and International Nuclear Information System (INIS) representatives from the following source.

Office of Scientific and Technical Information

P.O. Box 62

Oak Ridge, TN 37831

Telephone 423-576-8401

Fax 423-576-5728

E-mail reports@adonis.osti.gov

Web site http://www.osti.gov/products/sources.html

Reports produced after January 1, 1996, are generally available via the DOE Information Bridge.

Web site http://www.doe.gov/bridge 


\section{DISCLAIMER}

This report was prepared as an account of work sponsored by an agency of the United States Government. Neither the United States Government nor any agency thereof, nor any of their employees, make any warranty, express or implied, or assumes any legal liability or responsibility for the accuracy, completeness, or usefulness of any information, apparatus, product, or process disclosed, or represents that its use would not infringe privately owned rights. Reference herein to any specific commercial product, process, or service by trade name, trademark, manufacturer, or otherwise does not necessarily constitute or imply its endorsement, recommendation, or favoring by the United States Government or any agency thereof. The views and opinions of authors expressed herein do not necessarily state or reflect those of the United States Government or any agency thereof. 


\section{DISCLAIMER}

Portions of this document may be illegible in electronic image products. Images are produced from the best available original document. 
ORNL-6950

\title{
AN ECONOMETRIC ANALYSIS OF THE ELASTICITY OF VEHICLE TRAVEL WITH RESPECT TO FUEL COST PER MILE USING RTEC SURVEY DATA
}

\author{
David L. Greene \\ Center for Transportation Analysis \\ Oak Ridge National Laboratory \\ James Kahn \\ Department of Economics \\ and \\ Robert Gibson \\ Systems Development Institute \\ University of Tennessee
}

March 1999

\author{
Prepared by the \\ OAK RIDGE NATIONAL LABORATORY \\ Oak Ridge, Tennessee 37831 \\ managed by \\ LOCKHEED MARTIN ENERGY RESEARCH CORP. \\ for the \\ U. S. DEPARTMENT OF ENERGY \\ under contract DE-AC05-96OR22464
}

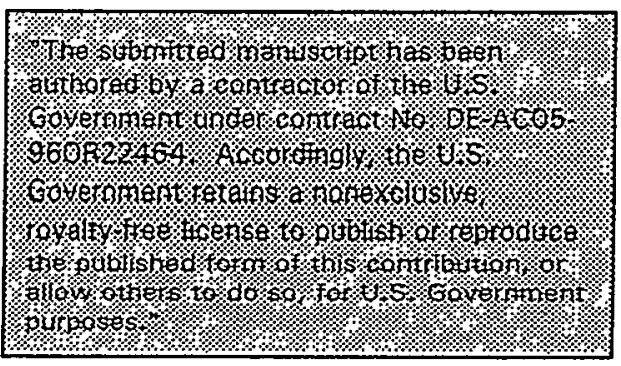




\section{LIST OF FIGURES}

Figure 1. U.S. Households by Vehicle Ownership $\ldots \ldots \ldots \ldots \ldots \ldots \ldots \ldots \ldots$

\section{LIST OF TABLES}

Table 1. Recent Estimates of the Long-Run Direct Rebound Effect ............ 14

Table 2. Comparison of Fuel Cost Elasticity of Vehicle Travel Estimates From

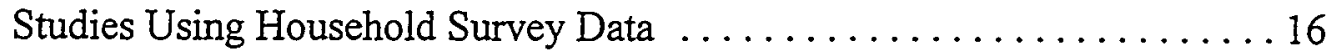

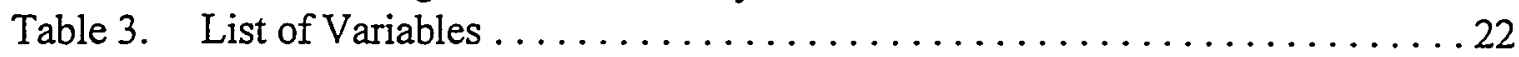

Table 4. Data Screening Criteria by Number of Vehicles per Household ........23

Table 5. Distribution of Vehicles by Household Vehicle Ownership Level . . . . . . 27

Table 6. One-Vehicle Households . . . . . . . . . . . . . . . . . . . . . 32

Table 7. Two-Vehicle Households ................................ 34

Table 8. Three-Vehicle Households .............................. 37

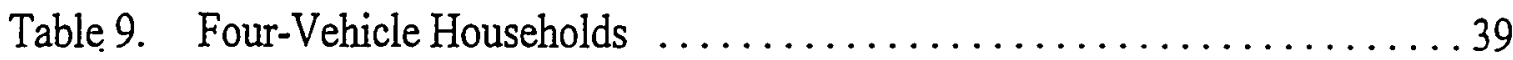

Table 10. Five-Vehicle Households $\ldots \ldots \ldots \ldots \ldots \ldots \ldots \ldots \ldots \ldots \ldots \ldots$

Table 11. Fuel Cost-per-Mile Elasticity of Vehicle Travel for All Vehicle Ownership Levels . ................... 41 


\begin{abstract}
This paper presents the results of econometric estimation of the "rebound effect" for household vehicle travel in the United States based on a comprehensive analysis of survey data collected by the U.S. Energy Information Administration (EIA) at approximately three-year intervals over a 15 -year period. The rebound effect is defined as the percent change in vehicle travel for a percent change in fuel economy. It summarizes the tendency to "take back" potential energy savings due to fuel economy improvements in the form of increased vehicle travel. Separate vehicle use models were estimated for one-, two-, three-, four-, and five-vehicle households. The results are consistent with the consensus of recently published estimates based on national or statelevel data, which show a long-run rebound effect of about +0.2 (a ten percent increase in fuel economy, all else equal, would produce roughly a two percent increase in vehicle travel and an eight percent reduction in fuel use). The hypothesis that vehicle travel responds equally to changes in fuel cost-per-mile whether caused by changes in fuel economy or fuel price per gallon could not be rejected. Recognizing the interdependency in survey data among miles of travel, fuel economy and price paid for fuel for a particular vehicle turns out to be crucial to obtaining meaningful results.
\end{abstract}




\section{AN ECONOMETRIC ANALYSIS OF THE ELASTICITY OF VEHICLE TRAVEL WITH RESPECT TO FUEL COST PER MILE USING RTEC SURVEY DATA}

\section{INTRODUCTION}

U.S. energy policy for transportation has focused on technological solutions. Automotive fuel economy standards and the Partnership for a New Generation of Vehicles (PNGV) are designed to increase the fuel economy of motor vehicles without directly affecting the price of fuel. As Khazzoom (1980) has pointed out, improving technical energy efficiency reduces the cost of energy services, and thereby tends to increase the consumption of goods and services that use energy. In this case, increased vehicle travel will boost demand for fuel that, to some extent, will offset the reduction in energy use due to a technical efficiency improvement (Blair et al., 1984). This "rebound" or "takeback" effect is a key determinant of the role that technologically-based energy efficiency improvements can play in reducing carbon dioxide emissions (Khazzoom et al., 1990). If the rebound effect approaches 100 percent of the direct effect of efficiency improvement, then technical efficiency gains alone cannot reduce total energy use or carbon emissions. If, on the other hand, the rebound effect is on the order of ten percent of the direct effect, technological progress in energy efficiency is likely to be the key to controlling world greenhouse gas emissions.

Three principle types of rebound effect have been identified (Greening and Greene, 1997). ${ }^{1}$ Increased usage of energy services induced by the reduced price of energy services due to greater energy efficiency will is called the direct rebound effect. This works exactly as would the reduction in price of any commodity. It induces an incomecompensated substitution effect in favor of the commodity whose price has fallen and an income effect, due to the fact that the lower price confers an increase in real income on the consumer. Holding the prices of other commodities constant, the reduction in the cost of energy services implies that the consumer has a little more money to spend on all goods and services. Other goods and services also require energy, and so total energy use will increase in other areas not directly affected by the energy efficiency improvement. This leads an indirect rebound effect.

\footnotetext{
'We consider here only rebound effects resulting from realized efficiency improvements. A pure technological advance, such as the PNGV, would create an opportunity to trade-off part of the potential increase in fuel economy for other desirable attributes such as greater acceleration or weight. We do not consider this effect here.
} 
Changes in the prices of firms' outputs and changes in the demand for inputs caused by income and substitution effects will propagate throughout the economy. These general equilibrium effects involve both producers and consumers and represent the results of myriad adjustments of supply and demand in all sectors. In general, such impacts can only be estimated by means of economy-wide general equilibrium models. However, the most important general equilibrium effect is likely to be the adjustment of energy prices to reduced demand.

Rebound effects are critical to the relevance of technological change as a strategy for solving the greenhouse gas problem because their combined impact determines whether technological improvements in energy efficiency can greatly reduce greenhouse gas emissions or not. Some argue that technological improvements ultimately cannot reduce energy use but can only increase it (e.g., Brookes, 1990). Others counter that rebound effects are generally small in comparison to direct energy savings and can safely be ignored (e.g., Grubb, 1990). If the rebound effect is such that any change in technical energy efficiency results in an increase or at best no change in energy consumption, then improving technology alone cannot solve the greenhouse gas problem. As a result, understanding the rebound effect is essential to formulating effective policies to mitigate anthropogenic greenhouse gas emissions.

This paper presents new evidence concerning the direct rebound effect of vehicle fuel economy via increased travel derived from surveys of U.S. households conducted by the U.S. Department of Energy (DOE), EIA (1997b) over a fifteen year period. Indirect and general equilibrium effects are not considered. The Residential Transportation Energy Consumption Surveys (RTECS) represent the most comprehensive source of information available on household vehicle use, fuel economy, and fuel prices. They are the only databases that provide for each household vehicle an odometer-based vehicle use estimate, a rigorous fuel economy estimate, and the estimated average price paid for fuel for that vehicle. Moreover, the combined RTECS databases provide a large enough sample to estimate separate vehicle use models for households owning one, two, three, four, and five vehicles. It seems reasonable to anticipate that a change in the use of one household vehicle may significantly affect the usage of the others.

Recent econometric studies of the rebound effect based on state or national aggregate data have uniformly concluded that the direct rebound effect for vehicle fuel economy is relatively small, in the vicinity of 10 percent in the short-run (one year) and 20 percent in the long-run. However, some have raised questions about the accuracy and validity of the aggregate national vehicle travel and fuel economy data (Schipper, et al., 1993; Nivola and Crandall, 1995, pp. 125-126; percent, 1996). Because of this, and for general purposes of confirming the recent conclusions about the size of the rebound effect, it is appropriate to look to estimates based on disaggregate survey data. The evidence produced by previous studies based on survey data, however, does not reveal the same degree of consensus and contains some much higher (as well lower) estimates of the 
rebound effect. Most studies to date have used survey data for a single year only (Puller and Greening, 1996 and 1997, and Goldberg, 1996 are important exceptions). The results obtained in this study indicate that a comprehensive estimate of the rebound effect for all household vehicles in the United States derived form the full complement of RTECS data is about 20 percent, consistent with the consensus of recent aggregate studies. 
<smiles>[Li]</smiles> 


\section{THEORY}

This paper examines the effect of changes in the energy efficiency of passenger vehicles on the intensity of their use. Household vehicle ownership levels are assumed to be constant. We recognize that fuel economy affects the total cost of vehicle ownership and therefore should have an effect in the long-run on levels of vehicle ownership. Apart from a pure technological advance, improvements in fuel economy are not costless and require trading off of higher purchase price, or some other attribute, such as acceleration, for miles per gallon. Such trade-offs reduce the incentive to change levels of vehicle ownership so that there is no ineluctable relationship between fuel economy and vehicle ownership. The analysis presented here does not address the question of how changes in fuel economy may affect levels of vehicle ownership, but rather focuses on the intensity of use of all existing household vehicles. ${ }^{2}$

\subsection{ECONOMIC THEORY OF THE REBOUND EFFECT}

Increasing fuel efficiency will directly lower fuel consumption, because with greater efficiency, less fuel is needed per mile driven. However, increasing fuel efficiency also reduces the cost of driving. This lowering of the cost of driving implies that, ceteris paribus, more miles will be driven. Although both of these effects seem evident from economic intuition, it is useful to formalize the intuition and derive a demand curve for distance traveled in order to provide more specific guidance for the empirical examination of the rebound effect.

When studying the rebound effect, researchers can use either aggregate or household data. Aggregate data (such as annual observations on nation-wide or state-wide data) mask important information because the aggregation process smoothes out variation. Household level data maintains this source of variation, but generates several other potential problems. First, previous studies have focused on household level data in a given survey year, eliminating inter-temporal variation from the analysis. We attempt to rectify this problem by using survey data from surveys in different years as a pooled data set. ${ }^{3}$ The second problem is that as one disaggregates from the national level, explanatory

${ }^{2}$ For the past several years, the cost of gasoline and oil have averaged about 12 percent of total vehicle ownership costs (AAMA, 1997). Assuming an elasticity of total vehicle ownership costs of about -1.0 (e.g., McCarthy, 1996; Bordley, 1993), would imply that a one percent reduction in fuel costs would lead to roughly an 0.1 percent increase in vehicle ownership and, assuming constant vehicle usage rates, an 0.1 percent increase in vehicle travel.

${ }^{3}$ A true pooled sample which has panel data properties and for which one could employ fixed effect or random effects models is not possible in this case, because the same households 
variables that could be regarded as exogenous in the aggregate context become choice variables and therefore endogenous.

Since the transportation services produced by passenger cars and light trucks are not directly purchased in the market, it is appropriate to look at the consumer utility maximization problem in the context of the household production model. In this model, consumers value market goods as inputs to final service flows which they produce using their time, public goods and the purchased inputs (see Becker, 1965).

Following Bockstael and McConnell's (1981) application of the household production approach to recreational activity, we apply the model to transportation activity by defining a "quantity" transportation final service flow which is a function of vehicle miles and a "quality" related transportation flow which is function of the attributes of the vehicle such as comfort, safety, performance, and so on.

If each family drove only one car, it would be easy to define the quantity transportation final service flow as total miles (e.g., Puller and Greening, 1997). However, if families have more than one car, it is likely that the quantity transportation final service flow is a non-linear function of total miles, as owning several cars allows the family the flexibility to make different trips at the same time. The more cars, the less constrained are the travel decisions. Because of this, it would be inappropriate to define the quantity variable as simply the sum of miles from each vehicle. We will define this quantity variable (TRANS) as an unspecified nonlinear function of the miles driven with each vehicle. In equation (1), TRANS is defined for the cases of families with two cars, where $M_{1}$ represent the total miles of vehicle one, and $\mathrm{M}_{2}$ represents the total miles of vehicle two. ${ }^{4}$

$$
\operatorname{TRANS}=\operatorname{TRANS}\left(M_{1}, M_{2}\right)
$$

The quality variable could be defined as either a total quality variable or quality per mile. Following Bockstael and McConnell (1981), we will define the quality variable as "per unit of the quantity variable," with a small but important difference. Rather than define the quality variable as per unit TRANS, we will define a separate quality variable related to the driving in each vehicle, and measure them as per unit $\mathrm{M}_{1}$ and $\mathrm{M}_{2}$. For example, if one were thinking of the quality variable solely as a function of safety, then the quality

do not remain in the surveys from one sample period to another. However, our data set still includes both cross-sectional and time series sources of variation.

${ }^{4}$ Our approach estimates separate demand functions for families with different numbers of vehicles. This approach does not explain the decision of how many vehicles to own. See (Train, 1986; Goldbert, 1996; Hensher et al., 1990; Mannering and Winston, 1985, e.g) for an examination of this issue. 
variable would be some function of the probability of injury and death per mile driven. One could have a separate quality variable for each vehicle or have the quality variable be additively separable in the attributes of the car. Either formulation is conceptually equivalent, and we will employ separate quality variables for each car so that when one expands to other dimensions in addition to safety, the quality variable for vehicle $i$ will be some function of the attributes of vehicle $i$, as in Equation (2). The cost of quality is related to the durable characteristics of the car (the vector $A_{i}$ ), and can be expressed as the depreciation $\left(\delta_{i}\right)$ associated with each vehicle, as in equation (3),

$$
\begin{gathered}
Q_{i}=Q_{i}\left(A_{i}\right) \\
\delta_{i}=f_{i}\left(A_{i}\right)
\end{gathered}
$$

The utility maximization problem is to maximize (where $\mathrm{X}$ is a composite private good)

$$
U=U\left(X, \operatorname{TRANS}, Q_{l}, \ldots Q_{n}\right)
$$

subject to the budget constraint,

$$
\begin{gathered}
I=P_{\not X} X+\sum_{i=1}^{n} M_{i}\left(\frac{P}{M P G}+\delta_{i}+O C_{i}\right) \\
\text { where } \delta_{i}=f_{i}\left(A_{i}\right)
\end{gathered}
$$

Our goal is to derive demand functions for vehicle miles, which are not the final service flows in this consumer maximization problem, but inputs. Therefore demand functions for the $M_{i}$ must be derived from the demand functions for the final service flow of TRANS.

Following Bockstael and McConnell (see also Kahn and Kemp, 1985), the demand functions are derived from the dual to the utility maximization problem. A costminimizing expenditure function is obtained by minimizing the cost of producing a fixed level of utility, which is equivalent to minimizing the cost of producing fixed levels of $X$, TRANS and all the $\mathrm{Q}_{\mathrm{i}}$ (equation 6). 


$$
\begin{aligned}
& E=E\left(X, P_{x^{\prime}} I, M P G_{1}, \ldots M P G_{n^{\prime}} \delta_{1}, \ldots \delta_{n^{\prime}} O C_{l^{\prime}}, \ldots . O C_{n^{\prime}} T R A N S\right. \text {, } \\
& \left.M_{1}, \ldots M_{n^{\prime}} Q_{l^{\prime}}, \ldots Q_{n^{\prime}} A_{1}, \ldots A_{n}\right)
\end{aligned}
$$

Marginal cost functions for the final service flows can be derived by differentiating the expenditure function with respect to the $\mathrm{M}_{\mathrm{i}}$, and the marginal costs serve as implicit prices from which one can derive demand functions for the final service flows (TRANS, and the $Q_{i} s$ ). An important conceptual and empirical question is the interdependency of the demand functions for the final service flows. Bockstael and McConnell (1981) demonstrate that the demand functions will be interdependent if there is jointness in production of the final service flows, or if quality is defined as per unity quantity, necessitating multiplication by quantity in the cost function.

We argue that the jointness in producing household travel with multiple vehicles arises primarily from the ability to deliver household members to different places at the same time. Clearly, this cannot be done with a single vehicle. The quality of travel by each vehicle, however, has little relevance to joint production but rather adheres to the miles produced by the vehicle in question: Mathematically, we do not have either joint production of final service flows, or a multiplicative relationship between quantity and quality in the cost function. What we have is quantity as a nonlinear function of quantity inputs (the $M_{i}$ ) and a multiplicative relationship between the quality inputs of vehicle $i$ and the quantity input of vehicle $i$ in the cost function (but no relationship between the quantity input of vehicle $i$ and the quality input in vehicle $j$ ). This implies that the demand for miles from vehicle $i$ will be a function of the number of miles driven by each other vehicle, and the quality of vehicle $i$, but not the quality of each other vehicle.

$$
\begin{gathered}
D_{T_{i}}=g_{i}\left(P_{x}, P_{f}, A_{i}, M P G_{i}, \delta_{i}, O C_{i}, M_{l}, \ldots, M_{n}\right) \\
\text { for } j=1 \text { thru } J, j \neq i
\end{gathered}
$$

This key assumption greatly simplifies the vehicle use equations

\subsection{ENDOGENEITY OF RIGHT-HAND SIDE VARIABLES}

The right-hand side of equation (7) is interesting to examine in terms of which variables are endogenous, and which variables are likely to be correlated. Endogeneity may arise because certain right hand side variables are chosen by the consumer, rather than exogenously determined (Goldberg, 1996). In this context, the most important variable is MPG. MPG is chosen by consumers and at vehicle purchase is likely to be a function of 
miles expected to be driven as well as the price of fuel at that time. Because cars are less energy efficient on shorter trips, miles driven also affect MPG. The price of fuel is also likely to be an endogenous variable. This claim may strike some as curious, as the price of oil is determined in world oil markets. However, it is important to think of the choices the consumer faces. Although the price of gasoline at a particular gasoline station is exogenous to the consumer, the consumer can choose the price of gasoline by choosing a gasoline station, a grade, or a level of service. For example, the consumer may opt to pay a higher price to purchase at a more convenient, cleaner or safer location. In addition, the consumer chooses a price/quality bundle where quality characteristics may include octane, additives, and purity.

Since our empirical work is based on the RTEC surveys, we are to a certain degree constrained by the limited number of variables in the survey data sets. Unfortunately, we do not have data on $P_{x}, \delta$, or OC. The lack of data on $P_{x}$ is not likely to present problems, because it can be viewed to be approximately constant across individuals, and therefore would be subsumed in the constant term of the regression. However, $\delta$ and $\mathrm{OC}$ are not likely to be constant across vehicles. To the extent that the variation is random, this will only influence the estimation process by creating more white noise. However, $\delta$ and OC are more likely to vary systematically across vehicles in a fashion that may be correlated with other variables of interest such as MPG, which could cause biases in estimated coefficients of these variables. This problem is discussed further below.

Analysis of the demand for travel on a vehicle by vehicle basis substantially increases the simultaneity of the system, since one vehicle is a substitute good for another. In the one vehicle case, there are three potentially simultaneous equations (one each for $M, P_{f}$ and MPG). In the two vehicle case there would be six simultaneous equations, while in the three vehicle case the system would include nine simultaneous equations.

Let the variable $x_{i}$ represent the own vehicle characteristics as well as the relevant household characteristics for vehicle $i=1,2,3$. Let $M_{i}$ represent the annual miles of vehicle $i$, and let $a_{i}$ and $b_{i j}$ be parameters to be estimated. The simultaneous equation system for the three-vehicle household at a minimum consists of three vehicle equations (8).

$$
\begin{aligned}
& M_{1}=a_{1} x_{1}+b_{12} M_{2}+b_{13} M_{3} \\
& M_{2}=a_{2} x_{2}+b_{21} M_{1}+b_{23} M_{3} \\
& M_{3}=a_{3} x_{3}+b_{31} M_{1}+b_{32} M_{2}
\end{aligned}
$$

If we structure the database such that each vehicle appears once and only once as "first," "second," and "third" vehicle then nothing distinguishes one vehicle from another apart from its characteristics. As a result, all the a's would be equal and all the b's would too. Due to the conventions of the software we used, we must still estimate a full set of 
equations in order for the endogenous variables to be properly recognized. However, there will be no differences in the estimated coefficients across vehicles.

As we have noted, fuel economy (MPG) and fuel price (P) must be treated as endogenously determined in order to obtain unbiased estimates of their relationship to vehicle use. This implies three simultaneous equations for each of the three vehicles, for a total of nine simultaneous equations. Each block of three equations will have the following structure (9).

$$
\begin{aligned}
& M_{1}=a_{11} x_{11}+c_{11} M P G_{1}+d_{11} P_{1}+b_{12} M_{2}+b_{13} M_{3} \\
& M P G_{1}=a_{12} x_{12}+c_{12} M_{1}+d_{12} P_{1} \\
& P_{1}=a_{13} x_{13}+c_{13} M_{1}+d_{13} M P G_{1}
\end{aligned}
$$

In this structure, the miles of use for vehicles two and three directly affect the use of vehicle one, but only indirectly influence its fuel economy or the price paid for its fuel via their effect on its usage. All nine variables are recognized as simultaneously determined, however.

\subsection{TRAVEL COST, THE PRICE OF FUEL AND FUEL EFFICIENCY}

A relatively straightforward definition of the cost of driving a mile can be computed as the sum of fuel costs, other operating costs, and depreciation. Mathematically, this can be represented as in Equation (10), where TCPM represents total cost per mile. Equation (10) is simple a restatement of a portion of the household production cost function of equation (5).

$$
T C P M=a_{o} \frac{P}{M P G}+a_{1} O C+a_{2} \delta
$$

Equation (10) indicates that if consumers behave in a rational fashion (minimizing the cost of a given distance traveled) they should react symmetrically with respect to changes in $P$ and MPG. That is, a one percent increase in the price of fuel should affect the driving decision the same way as a one percent reduction in MPG. We test this hypothesis below and find that it cannot be rejected for any vehicle ownership level.

The direct rebound effect is therefore equivalent to the negative of the elasticity of vehicle miles with respect to fuel cost-per-mile (assuming that changes in MPG do not affect $\delta$ or $\mathrm{OC}$ ). The effect of an exogenous change in energy efficiency, e (defined here as gallons 
of fuel per mile or $1 / \mathrm{MPG}$ ), on the demand for fuel, $F$, can be readily derived, making use of the fact that $F=\mathrm{Me}$.

$$
\begin{gathered}
\frac{d F}{d e}=e \frac{d M}{d(e P)} P+M \\
\beta_{F, e}=\frac{d F}{d e} \frac{e}{F}=\frac{d M}{d(e P)} \frac{e P}{M}+\frac{e M}{F}=\beta_{M, e P}+1
\end{gathered}
$$

Equation (11) shows that the elasticity of fuel use with respect to a change in energy efficiency, $\beta_{F, e}$, is one plus the elasticity of vehicle travel with respect to fuel cost per mile, $\beta_{\mathrm{M}, \mathrm{eP}}$. If there were no rebound effect, we would have $\beta_{\mathrm{M}, \mathrm{eP}}=0$, and therefore, $\beta_{\mathrm{F}, \mathrm{c}}=1$. A one percent decrease in gallons per mile would produce exactly a one percent decrease in fuel consumption. The more elastic vehicle travel with respect to fuel costper-mile (the closer $\beta_{\mathrm{M}, \mathrm{eP}}$ is to -1 rather than 0 ), the larger the rebound effect. 


\section{PREVIOUS STUDIES}

Over the past three decades, researchers have produced dozens of econometric analyses of the demand for gasoline and vehicle travel in the United States (e.g., see Dahl, 1994, 1986; Dahl and Sterner, 1991). Most empirical evidence on the size of the direct rebound effect for passenger cars and light trucks comes from studies based on national or statelevel data. Over the past ten years, these aggregate studies have consistently shown a small direct rebound effect of about +0.1 for the short run (one year), increasing to perhaps as much as +0.2 to +0.3 for the ultimate long-run rebound effect. Studies based on disaggregate survey data have shown less consistent results, with rebound effects ranging from zero to +0.5 and higher. In this section the existing evidence is briefly reviewed, and possible explanations are suggested for the convergence of estimates from aggregate studies and lack of convergence for the survey-based analyses.

Estimates of the direct rebound effect come from a variety of econometric studies using two different data sources: (1) time series of national or state data and (2) surveys of household vehicle use. The national or state data generally include all light-duty vehicles (passenger cars plus light trucks) whether owned by firms or households. ${ }^{5}$ The time series data also include wide variations in fuel prices and substantial variations in fuel economy, at least those published in the last five to ten years. All of the survey studies except those by Goldberg (1996) and Puller and Greening (1997) rely on data for a single year. Thus, variation in fuel cost per mile comes from differences in fuel economy across vehicles and to a lesser extent from variations in fuel prices due to geography or consumer choice of fuel grade and level of service. The studies based on national or state time series are reviewed first, followed by the survey evidence.

For motor vehicles, the direct rebound effect is equivalent to the negative of the fuel-costper-mile elasticity of vehicle use, $\beta_{\mathrm{M}, \mathrm{ep}}$. Several estimates of this parameter were made in the course of estimating models of gasoline demand during the 1970s and 1980s. In her comprehensive review of gasoline demand elasticities published between 1973 and 1984, Dahl (1986) cites a range of estimates of -0.21 to -0.50 for models estimated using annual national or state data. Among these studies are Wheaton's (1982) estimate of -..50 based on data for 25 countries for the single year of 1972 and Kouris' (1983) estimate of -0.235 for the period 1964-81 for the United States. In a survey of travel demand elasticities, Goodwin (1992) reports a central tendency estimate of -0.33 for $\beta_{\mathrm{M}, \mathrm{eP}}$, based on 11 international studies published between 1976 and 1986.

${ }^{5}$ The Energy Information Administration (1997b, p. xvi) estimates that U.S. households consumed 90.6 billion gallons of motor fuel in 1994. This compares with an estimated 112.2 billion gallons consumed by all U.S. passenger cars and light trucks in that year (FHWA, 1997, table VM201A). 
More recent studies have estimated $\beta_{\mathrm{M}, \mathrm{eP}}$ for the United States based on the richer experience with fuel price and fuel economy changes of the past quarter century, and have produced very consistent results. Using aggregate national data, first Mayo and Mathis (1988), then Gately (1990; 1992), Greene (1992), Jones (1993), and Nivola and Crandall (1995) all found fuel cost per mile elasticities of travel of less than -0.3 , even in the long-run (Table 1). Most estimates fell in the vicinity of -0.10 to -0.25 . Haughton and Sarkar (1996) confirmed these results using a time series of state-level data. They found a short-run elasticity of -0.17 and a long-run elasticity of -0.22 .

Table 1. Recent Estimates of the Long-Run Direct Rebound Effect

\begin{tabular}{lccc}
\hline Authors & $\begin{array}{c}\text { Rebound } \\
\text { Effect }\end{array}$ & $\begin{array}{c}\text { Years of } \\
\text { Data }\end{array}$ & $\begin{array}{c}\text { Type of } \\
\text { Data }\end{array}$ \\
\hline Blair et al. (1984) & -0.21 (midpoint) & $1967-76$ & Florida state, monthly \\
Mayo and Mathis (1988) & $-0.221^{\mathrm{b}}$ & $1958-84$ & U.S. National, annual \\
Gately (1990) & -0.09 & $1966-88$ & U.S. National, annual \\
Greene (1992) & & $1966-89$ & U.S. National, annual \\
$\quad$ Linear model & -0.05 to -0.19 & & \\
$\quad$ Log-linear & -0.13 & & \\
Jones (1993) & & $1967-90$ & U.S. National, annual \\
$\quad$ Model I linear & -0.13 & & \\
$\quad$ Model III linear & -0.31 & & \\
$\quad$ Model I log-linear & -0.27 & & \\
$\quad$ Model III log-linear & -0.31 & & U.S. National, annual \\
Pickrell (1994) & -0.23 & & U.S. 50 States plus D.C., \\
annual & & & \\
$\quad$ Moughton and Sarkarc (1996) & -0.22 & $1970-91$ & \\
$\quad$ Model F & -0.23 & &
\end{tabular}

a Calculated from Table 2 in Blair et al., assuming a fuel price of 33 cents/gallon (1967 \$), an average miles per gallon or 14.0 , and monthly miles traveled of 4,250 millions. The GLS coefficient estimate of -386.4 , recommended by the authors, was used.

b The lagged dependent variable was not significant in Mayo and Mathis' VMT equation, having a value of 0.15 but a t-statistic of 0.73 . Nonetheless, had this coefficient been used to estimate a long-run cost per mile elasticity of VMT that would have been -0.25 .

c These are the only two models presented by Haughton and Sarkar that include all the statistically significant effects the authors identified. 
A likely explanation for the convergence of recent estimates of the rebound effect is that the very large fluctuations in fuel prices that have occurred since 1973, combined with the substantial increase in vehicle fuel economy, comprise a well-designed "experiment." This statistical experiment may have such a strong signal concerning fuel prices and vehicle travel that estimation results are robust to model formulation and estimation method. This conjecture is supported by the studies of Greene (1992), Jones (1993), and Haughton and Sarkar (1996) which rigorously tested alternative methodologies and obtained similar results.

A number of econometric analyses have used household survey data to estimate the sensitivity of vehicle use to fuel price and fuel efficiency. A special feature of several of the studies is the analysis of how households owning more than one vehicle adjust the usage of their portfolio of vehicles in response to differences in fuel cost per mile. Using data from the 1990 Nationwide Personal Transportation Survey (NPTS), a recent econometric analysis estimated an overall gasoline price elasticity of VMT of -0.51 (Walls et al., 1993, table 3). Elasticities were found to vary by household ownership level, with elasticity estimates of -0.29 for single-vehicle households, -0.41 for twovehicle households, and -0.78 for three-or-more-vehicle households (Table 2). These estimates compare reasonably well with older econometric studies by Archibald and Gillingham (1980, 1986, 1981b) and Train (1986). The Walls et al. (1993) analysis omits age of vehicle as an explanatory variable for vehicle miles. Vehicle usage is well known to be negatively correlated with vehicle age. Archibald and Gillingham (1980, 1981a, $1981 b)$ also do not account for the correlation between vehicle age and usage. Other models estimated using survey data that included age as a right-hand side variable (Golob et al., 1996; Goldberg6 ${ }^{6}$ 1996) produced cost per mile elasticities close to zero.

Two recent studies by Goldberg (1996) and Puller and Greening (1997) have made use of multiple years of Consumer Expenditures Survey (CES) data and have also addressed the question of simultaneity in vehicle use and fuel economy. The CES databases contain vehicle miles as reported by the household for each vehicle for each quarter. Households typically remain in the survey for four quarters. Both Puller and Greening (1997) and Goldberg (1996) added fuel economy and fuel price information to the CES survey, but used different data sources and different methods to impute these variables. In general, average federal test fuel economy values were matched to the $C E S$ vehicles based on make, model, model year and other factors. Fuel price data were regional averages, rather than prices actually paid by consumers. Puller and Greening excluded miles traveled for business purposes from their analysis.

${ }^{6}$ Goldberg (1996) does not actually include age as a variable but instead uses an instrumental variable approach to reduce the effect of omitted, correlated variables. She obtained a fuel cost elasticity estimate of -0.11 . 
Table 2. Comparison of Fuel Cost Elasticity of Vehicle Travel Estimates From Studies Using Household Survey Data

\begin{tabular}{|c|c|c|c|c|c|c|}
\hline Study & $\begin{array}{l}\text { 1-Vehicle } \\
\text { hhis }\end{array}$ & $\begin{array}{l}\text { 2-Vehicle } \\
\text { hhs }\end{array}$ & $\begin{array}{l}3 \text { or More } \\
\text { Vehicle } \\
\text { hhs/Total }\end{array}$ & Total & Type of Data & Sample Size \\
\hline $\begin{array}{l}\text { Puller \& Greening } \\
(1996,1997) \\
\text { Cost-per-mile (cpm) }\end{array}$ & & -0.485 & & -0.485 & U.S. CES, $1984-90$ & $\begin{array}{l}90,872 \text { interviews of } \\
34,535 \text { hhs. }\end{array}$ \\
\hline $\begin{array}{l}\text { Goldberg (1996) } \\
\text { OLS } \\
\text { Reduced Form } \\
\text { Instrumental Variable }\end{array}$ & & & & $\begin{array}{l}-0.22 \\
\text { not signif. } \\
\text { not signif. }\end{array}$ & U.S. CES, 1984-90 & 2,954 hhs. \\
\hline $\begin{array}{l}\text { Golob et al. (1996) } \\
\text { cpm }\end{array}$ & & $0.01^{\mathrm{a}}$ & & & California, 1993 & \\
\hline $\begin{array}{l}\text { Greening et al. (1995) } \\
\text { cpm }\end{array}$ & & -0.292 & & -0.292 & U.S. CES, 1990 & $\begin{array}{l}9,864 \text { quarterly hh. } \\
\text { records }\end{array}$ \\
\hline $\begin{array}{l}\text { Walls et al. (1993) } \\
\text { cpm }\end{array}$ & -0.288 & -0.408 & -0.782 & & U.S. NPTS, 1990 & $\begin{array}{l}22,317 \text { hhs. } 41,178 \\
\text { vehicles }\end{array}$ \\
\hline $\begin{array}{l}\text { Oum et al. (1992) } \\
\text { cpm }\end{array}$ & & & & -0.28 & $\begin{array}{l}\text { (Based on } 7 \text { studies } \\
\text { published from } 1984 \\
\text { to 1990) }\end{array}$ & \\
\hline $\begin{array}{l}\text { Hensher et al. (1990) } \\
\text { cpm }\end{array}$ & -0.222 & -0.317 & $-0.389 /-0.66^{\mathrm{b}}$ & & $\begin{array}{l}\text { Survey of Sydney, } \\
\text { Australia, 1981-82 }\end{array}$ & 1,172 hhs. \\
\hline
\end{tabular}




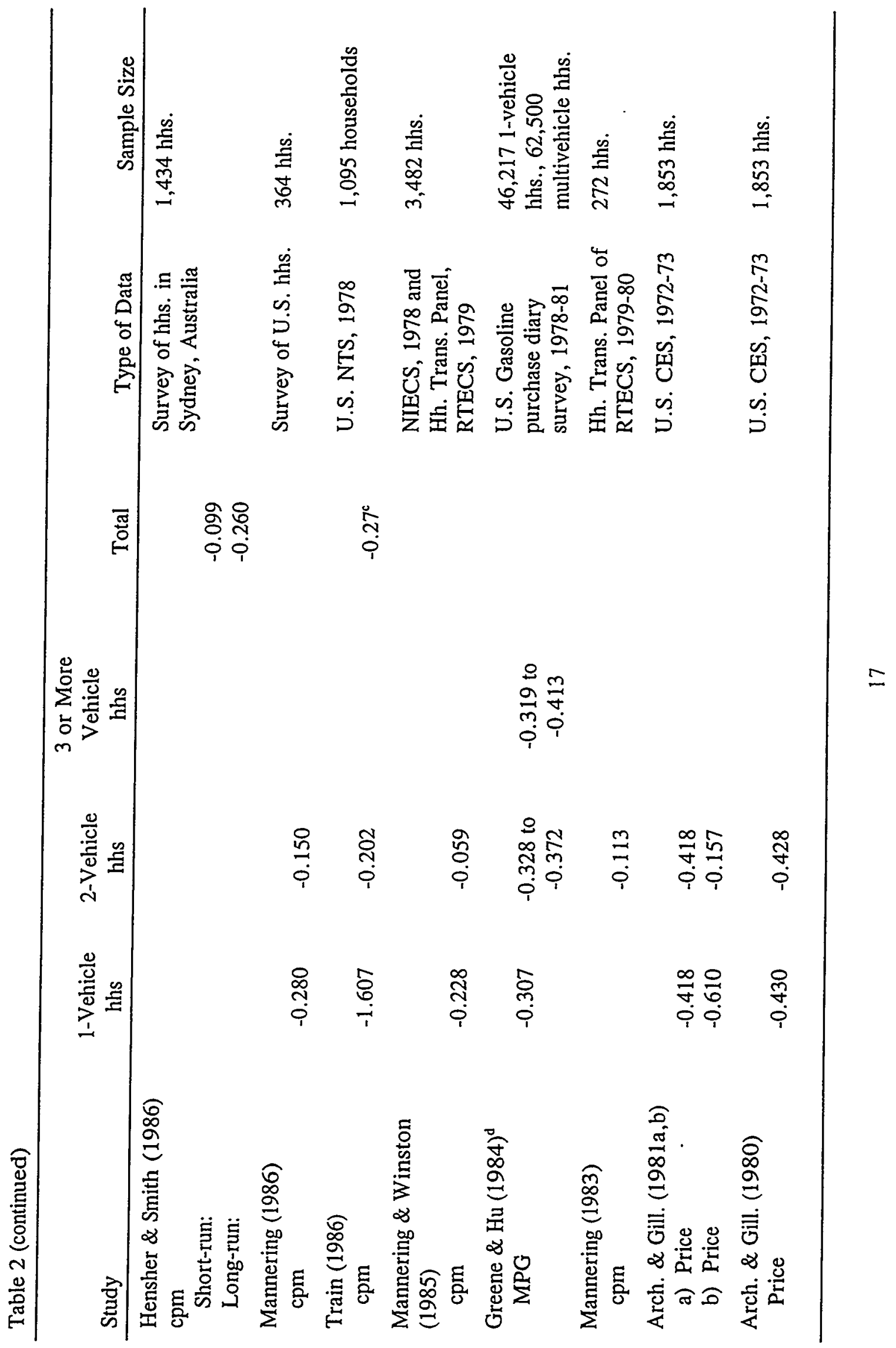


Table 2 (continued)

a Own fuel cost per mile was not a statistically significant variable, though the signs was as expected. Fuel cost per mile of the other vehicle was statistically significant and positively affected vehicle use. Thus, the net effect of an increase in fuel cost per mile would be an increase in vehicle travel.

${ }^{b}$ Hensher et al. estimate separate equations for three-vehicle and four-or-more-vehicle households.

c Train regresses the log of VMT on operating cost per mile and does not present elasticity estimates. To get the price elasticities in the table, Walls et al. (1993) multiplied their estimated coefficients by an average price per mile of 5.75 cents. The elasticities shown under " 3 or more vehicle hhs" are overall total elasticities calculated by Train via simulation in Tables 9.9 and 9.10.

d Rebound estimates are MPG elasticities. Fuel price was less elastic, ranging from -0.16 to -0.28 . Greene and Hu did not use a simultaneous equations estimation method.

CES = Consumer Expenditures Survey; NPTS = Nationwide Personal Transportation Survey;

NTS = National Transportation Survey; NIECS = National Interim Energy Consumption Survey 
Puller and Greening's (1997) model consisted of two equations, one for household vehicle miles and another for fuel economy, estimated by means of two stage least squares regression. The dependent variables were total household vehicle miles and average fuel economy, rather than individual vehicle statistics. They obtained an elasticity of vehicle travel with respect to fuel cost-per-mile of -0.49 based on CES data for the period 1984-1990. This result is approximately twice that obtained by recent studies using aggregate data, but it is consistent with Walls' et al. (1993) analysis of 1990 household survey data. Like Walls et al., Puller and Greening do not include vehicle age as an explanatory variable in the vehicle use equation. Puzzling, is Puller and Greening's finding that a one percent increase in the price of gasoline would lead to an 0.39 percent decrease in the fuel economy of household vehicles, a result that seems implausible.

Goldberg (1996) estimated a simultaneous model for vehicle choice and usage based on the same 1984-1990 CES data. The dependent variable was a particular vehicle's miles of travel, as opposed to the household totals used in Puller and Greening's study. It is important to note that Goldberg's analysis included only new cars, so that vehicle age was not a factor. When estimated via OLS, Goldberg (1996, p. 22) obtained an elasticity of fuel cost-per-mile of -0.22 . When simultaneous equation methods were used, fuel cost became statistically insignificant.

The issue of the interdependence of vehicle travel, fuel economy and fuel price in survey data is critical (for extensive treatments of this subject see, e.g., Mannering and Winston, 1985; Train, 1986; Hensher and Smith, 1986; Mannering, 1986; Mannering and Hensher, 1987). As Goldberg (1996, p. 5) points out, demand for durable goods, such as automobiles, and demand for their use are interdependent.

"Consumers choose the car type that maximizes the utility they expect to derive from driving it; hence, the expected usage of the car is likely to affect the vehicle type choice. The intensity with which the automobile is utilized, on the other hand, depends on the vehicle type....Both the indirect utility the consumer derives from owning an automobile, and the intensity of the car's usage are affected by factors unobserved to the econometrician that are included in the error terms of the utility function and utilization equation respectively.... Yet, in practice, it is likely that the error terms of the utility and usage functions include some common unobserved attributes, that induce correlation between the two error terms, and, hence, correlation between vehicle specific attributes and the error term of the usage equation."

Thus, household demand for travel, choice of vehicle fuel economy, and price paid for fuel are likely to be interdependent. Not only should one expect that a household will choose the miles it drives taking into consideration the fuel economy of its vehicles and the price of fuel, but one should also expect that it will choose the fuel economy of its 
vehicles taking into consideration the miles it expects to drive and the price of fuel. Given that fuel prices also vary with level of service and grade of fuel, one might even expect the choice of the price paid for fuel to be dependent on fuel economy and how much driving will be done. When the data consist of snapshots of particular households at a particular time, decisions about fuel economy, miles of travel and even fuel price should be treated as a system of simultaneous equations. Failure to do so could well result in biased estimates for the rebound effect.

A common "unobserved factor" that could be of great importance when using survey data is the effect of geography on travel, vehicle attributes and fuel price. Geography encompasses a panoply of factors including the spatial structure of development (density, land use patterns) and the quantity, quality and topography of transportation infrastructure. Such complex factors are very poorly represented by variables typically available in surveys. Walls et al. (1993), for example, used four regional dummy variables plus variables representing urban, suburban, and rural location to describe geography. Puller and Greening (1997) used a dummy variable to indicate whether a household lived in an urban area. Within such categories are large variations in development densities and infrastructure provision that can affect the characteristics of vehicles owned, how much they are driven, and even the price of fuel through state and local taxes. Failure to adequately represent the effects of geography on all three variables could be a significant source of estimation bias.

Another potentially important omitted factor is non-fuel operating cost, consisting of maintenance, depreciation, etc. Such data are often unavailable in survey databases and are very likely to be correlated with fuel costs. Changes over time in labor force participation rates and other lifestyle factors are other potentially important omitted factors.

Omitting vehicle age creates another common factor that can bias fuel cost-per-mile elasticity estimates because of its strong correlation with both fuel economy and vehicle use. Between 1974 and 1984 the fuel economy of new U.S. passenger cars doubled and that of light trucks increased by more than 50 percent. From 1984 to 1996 the fuel economy of new vehicles has not changed significantly. Thus, for a survey done in 1990, the fuel economy of the newest six or seven vintages would be essentially the same but MPG would drop off rapidly for older vintages. The correlation of vehicle use with age is well established: annual vehicle-miles decrease at a rate of about five percent per year with vehicle age (see e.g., Davis, 1997, table 3.10). Omitting age from the vehicle use equation could therefore induce a spurious correlation between fuel cost per mile and miles traveled, via their correlation with age. Interestingly, the study by Golob et al. (1996) which did include age as a variable, and that by Goldberg which included only new vehicles, concluded that fuel cost per mile had no statistically significant effect on vehicle use. The studies by Walls et al. and Puller and Greening, which omitted age, produced apparently significant cost-per-mile elasticities of -0.4 to -0.5 . 


\section{DATA}

Almost all of the data for this study come from the six Residential Transportation Energy Consumption Surveys (RTECS) conducted by the EIA (U.S. DOE/EIA, 1997) between 1979 and 1994. The RTECS are national sample surveys that have been conducted every three years since 1985. Data for this study were also obtained from the 1983 RTECS (U.S. DOE/EIA, 1985), and from the Household Transportation Panel (HTP) of the Residential Energy Consumption Survey, the predecessor to the RTECS conducted between 1979 and 1981 (U.S. DOE/EIA, 1982, 1983). Because of differences between the HTP and the subsequent RTECS data, the HTP data were used only in estimating the one-vehicle household equations. Each RTECS contains responses of thousands of U.S. households. The 1994 RTECS, for example, included 3,000 households and 6,000 vehicles. Vehicles included in the RTECS must be owned by household members, or used by them on a regular basis for personal transportation. Vehicles owned by a company but kept at home and available for use by household members are also included.

Two things make the RTECS data unique. First, data on vehicle miles for each vehicle are based on odometer readings at two points in time, rather than on the respondents' recollections. ${ }^{7}$ Second, vehicle fuel economy is estimated either from gasoline purchase diaries in surveys prior to 1988 , or is imputed from the vehicle identification number, a unique identifier of every vehicle in the United States. Imputed fuel economy estimates are based on U.S. EPA test estimates, corrected for real world operating conditions using methods that have been statistically validated by the EIA (U.S. DOE/EIA, 1997, p. 28). In the earlier surveys, gasoline prices are those actually paid by respondents and recorded in gasoline purchase diaries. In later surveys, U.S. Bureau of Labor Statistics price series were substituted.

All six RTECS surveys were combined into a single data base for this study. We used CPI-U consumer price index of the BLS to deflate prices and income to constant dollars. The data were then divided into five data bases according to the number of usable vehicle records per household. Thus, all vehicles from households with one usable vehicle record were separated into a one-vehicle household data base, those with two into the two-vehicle household data base, and so on up to five-vehicle households. Additional details about the construction of the data bases are provided as a appendix to this report. The data bases are available from the authors upon request. Table 3 contains the definitions of variables used in the vehicle use models.

In the following section, we present the results of econometric estimation of systems of vehicle use equations for one-, two-, three-, four-, and five-or-more-vehicle households.

\footnotetext{
${ }^{7}$ For households with only one odometer reading, the EIA used regression methods to impute the missing data.
} 
Table 3. List of Variables

\begin{tabular}{ll}
\hline Variable Name(s) & \multicolumn{1}{c}{ Definition } \\
\hline & \multicolumn{1}{c}{ Continuous Variables (logarithms) } \\
\hline LAGE & Vehicle age in years, computed as survey year-model year-1990 \\
LCAFE & $\begin{array}{l}\text { The weighted average fuel economy for all cars or light trucks sold in } \\
\text { the year in which the vehicle was manufactured. }\end{array}$ \\
LCPM & Fuel cost-per-mile in 1994 dollars per mile. \\
LCYL & Number of cylinders in vehicle's engine. \\
LCOST & Price paid for fuel in 1994 dollars per gallon \\
LDAYS & Number of days the household had the vehicle during the survey year. \\
LINC & Midpoint of RTECS income category in 1994 \$. \\
LMI & Annual vehicle miles. \\
LMPG & Miles per gallon. \\
LHH & Number of household members. \\
LVEHS & Average number of vehicles owned by the household during the year. \\
LEIAPR & National average price of all grades of gasoline. \\
\hline & \\
\hline CITY & Dummy Variables \\
JOB & Household is located within a central city. \\
LEAD & Vehicle was used on the job. \\
MID & Vehicle typically uses leased gasoline. \\
NCENT & Vehicle typically uses mid-grade gasoline. \\
NEAST & Household lives in the North Central Census Region. \\
NECC & Household lives in the North East Census Region. \\
& Household lives in the North East in a Central City, equal to \\
OCT & NEAST*CITY. \\
PKUP & Vehicle uses either premium or mid-grade gasoline. \\
PREM & Vehicle is a pick-up truck. \\
SOUTH & Vehicle uses premium gasoline. \\
TRUCK & Household lives in the South Census Region. \\
UTIL & Vehicle is a light truck. \\
VAN & Vehicle is a utility or sport utility vehicle. \\
WEST & Vehicle is a van or minivan. \\
YR83, YR85, & Household lives in the West Census Region. \\
YR88, YR91, YR94 & Survey year. \\
\hline & \\
\hline
\end{tabular}

a The prefix " $L$ " indicates the natural logarithm of the variable. 
Structuring the analysis in this way seems to imply that vehicle ownership status is a static phenomenon. In reality it is dynamic, with many households changing levels of ownership during a year. In addition, some households own vehicles they rarely or never use, (because of their state of repair or some other reason not recorded in the survey) so that ownership does not inevitably imply vehicle use. For these reasons, prior to estimating vehicle use models, we screened records to eliminate vehicles not in use, or those that were not identified as either passenger cars or light trucks or those with missing data for key variables such as number of cylinders. The precise screening criteria for each level of vehicle ownership are shown in Table 4.

Table 4. Data Screening Criteria by Number of Vehicles per Household

\begin{tabular}{ll}
\hline Criteria & Reject if: \\
\hline Annual gallons & $<25$ or $>6,000$ \\
Vehicle type & Not car or light truck \\
Number of cylinders & Missing value \\
CAFE & Missing value \\
Annual miles & Equal to 0 \\
Number of drivers & Equal to 0 \\
Average number of vehicles & Equal to 0 \\
Age +1 & $\leq 0$ \\
Days owned & Equal to 0 \\
\hline
\end{tabular}




\section{METHOD}

For one- to four-vehicle households, the vehicle use model comprises a three-equation simultaneous sub- system for each vehicle with the dependent variables being vehicle use, fuel economy, and fuel cost. For five-vehicle households, a simpler system is used consisting of two equations for each vehicle, with miles and fuel cost-per-mile the dependent variable, producing a ten-equation system. This was done to reduce the number of variables and equations to fit within the constraints of our econometric software.

It is well known that estimation of such simultaneous equation systems by means of ordinary least squares is inconsistent. In addition, since the system of equations applies to a single household, it is reasonable to assume that there will be correlation among the error terms of the equations for each vehicle. In such a case, the Three Stage Least Squares (3SLS) estimation method is both consistent and efficient (Hensher and Smith, 1986; Greene, 1993, pp. 610-612). The 3SLS procedure of the LIMDEP econometric software (Greene, 1995) was used here in all estimations. LIMDEP 3SLS permits the testing of linear constraints on parameter estimates by means of the Wald Test.

When estimating econometric models with survey data, it is generally desirable to experiment with a variety of combinations of variables of variables in each equation. One reason for this is that it is not obvious, a priori, which intuitively plausible variables will, in fact, be important. One might guess that a variety of dummy variables representing regions of the country or vehicle body types might be important but, as it turns out, few are. Unfortunately, such "mining" of the data invalidates the standard tests for statistical significance because particular results may be arrived at serendipitously or by an informal search for an implicit optimum result. When data are plentiful, as they are here, a solution is to divide the data set in two, using one part for exploring alternative model formulations and the other for formal testing of hypotheses. We adopted this approach by assigning a random number, uniformly distributed on the interval $[0,1]$, to each household. Those with a number $>0.5$ were assigned to the experimenting sample, the rest to the testing sample. There was not enough data to apply this method to four- and five-vehicle households. 



\section{RESULTS}

Today, the majority of U.S. households own more than one vehicle. Multiple-vehicle households increased from 22 percent of all households in 1960 to 55 percent in 1990 (Figure 1). Over the same period, the average number of persons per household declined from 3.4 to 2.7 (U.S. DoC, 1997, pp. 8, 59, 397) which makes the increasing ownership rates all the more remarkable. An even greater percentage of the vehicle stock is found in multiple-vehicle households, as the RTECS data in Table 5 show. More than 80 percent of all household vehicles are owned by multiple-vehicle households, and over 40 percent belong to households with three or more vehicles. Understanding how vehicles are used in the U.S. has become primarily a matter of how they are used by multiple-vehicle households.

Table 5. Distribution of Vehicles by Household Vehicle Ownership Level

\begin{tabular}{ccccc}
\hline $\begin{array}{c}\text { Number of } \\
\text { Vehicles }\end{array}$ & $\begin{array}{c}1994 \text { RTEC } \\
\text { Survey }\end{array}$ & $\begin{array}{c}\text { Initial Sample } \\
\text { Sizes }\end{array}$ & $\begin{array}{c}\text { Sizes After } \\
\text { Screening }\end{array}$ & $\begin{array}{c}\text { Post-screening } \\
\text { Distribution }\end{array}$ \\
\hline One & $18.5 \%$ & 5,279 & 4,270 & $15.6 \%$ \\
Two & $39.6 \%$ & 12,070 & 10,204 & $37.3 \%$ \\
Three & $24.7 \%$ & 9,747 & 7,773 & $28.4 \%$ \\
Four & $11.4 \%$ & 5,348 & 3,756 & $13.7 \%$ \\
Five & $5.8 \%$ & 2,150 & 1,320 & $4.8 \%$ \\
\hline
\end{tabular}

Source: Davis, S.C., 1998, table 10.7.

\subsection{ONE-VEHICLE HOUSEHOLDS}

Annual miles per vehicle in one-vehicle households depends on vehicle efficiency (miles per gallon) the price of fuel (dollars per gallon) and other household, vehicle, and location variables. Experimentation with various combinations of variables for each equation using the "test" half of the sample suggested the following as promising equations for testing on the second half of the sample. 


\section{8 \\ 图}
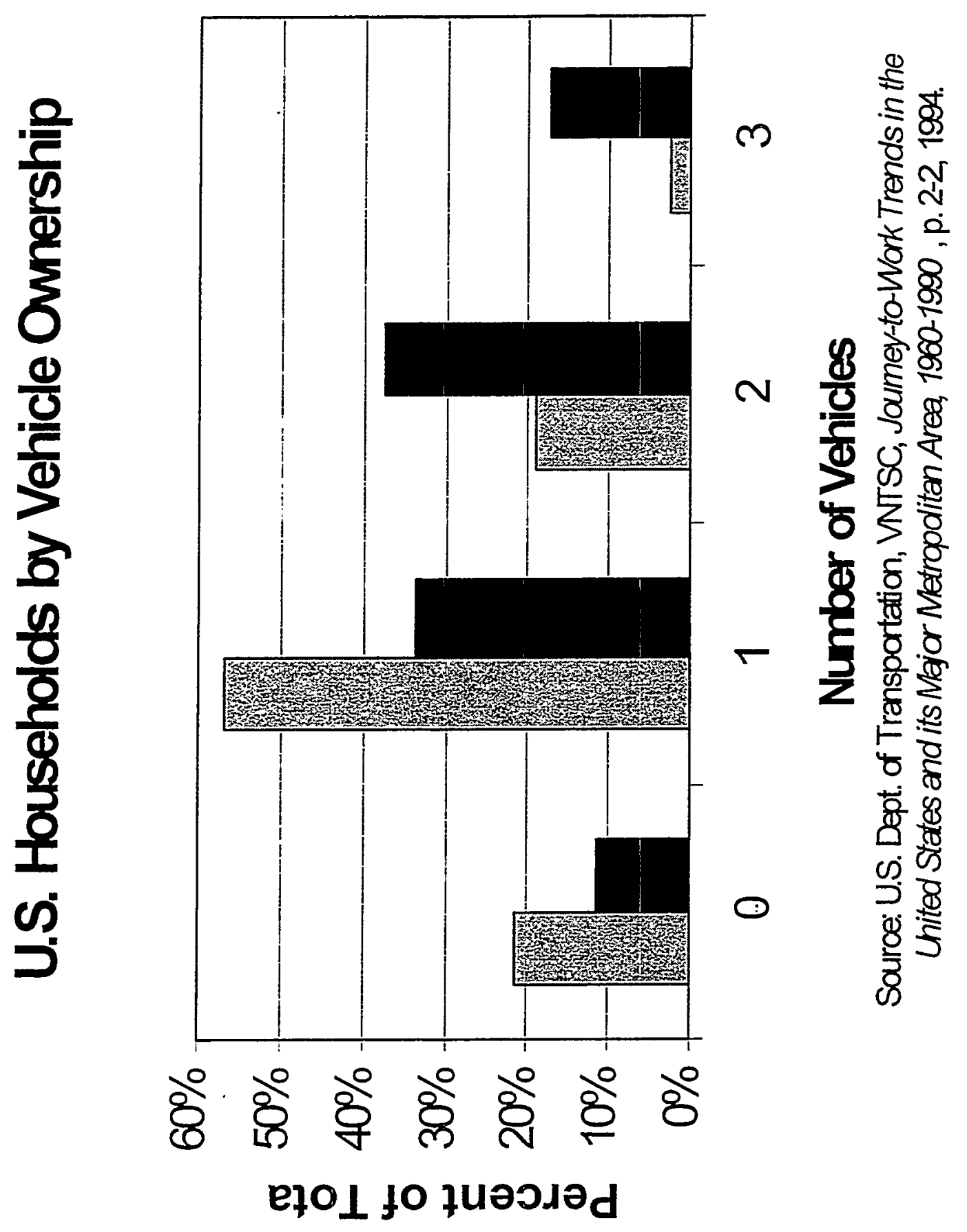


$$
\begin{aligned}
L M I= & a_{0}+a_{1} L A G E+a_{2} L C O S T+a_{3} L M P G+a_{4} L I N C+a_{5} L H H+a_{6} L V E H S+a_{7} J O B+ \\
& a_{8} \text { TRUCK } \\
L C O S T= & b_{0}+b_{1} L M I+b_{2} L M P G+b_{3} L E A D+b_{4} O C T+b_{5} S O U T H+b_{6} N C E N T+ \\
& b_{7} N E C C+b_{8} L E L A P R \\
L M P G= & c_{0}+c_{1} L M I+c_{2} L C A F E+c_{3} L C Y L+c_{4} L C O S T+c_{5} \text { TRUCK }
\end{aligned}
$$

The national average price of gasoline (LEIAPR) is entered as an exogenous variable in the fuel price (LCOST) equation to reflect the impacts of world oil price fluctuations, changes in taxes, etc., on the prices individual households pay for fuel. All continuous variables are logarithmic transformations of the original data, so that coefficients are partial, as opposed to system or total, elasticities.

Current fuel price appears in the vehicle efficiency equation but does not have the usual interpretation. Fuel economy is primarily determined by vehicle design and level of technology, factors influenced by fuel prices in the year in which the vehicle is purchased and in preceding years. Fuel economy is also partly determined by the fuel economy standards for the year in which the vehicle was manufactured (Greene, 1990). Since these are predetermined variables, vehicle fuel economy and current fuel price are not, in this respect, simultaneously determined. Current fuel price can only affect fuel economy by how the vehicle is used.

No attempt was made to model the relationship between historical fuel prices and vehicle fuel economy. Federal fuel economy regulations have been a binding constraint on the average fuel economy of new passenger cars sold in the United States since at least 1978 (Greene, 1990). Any serious attempt to represent the effect of fuel prices on fuel economy over this period would have to take their effect into account. Instead, we included the average fuel economy of all passenger cars (or light trucks, as appropriate) of the same model year, and the number of cylinders of a vehicle's engine as right-hand-side variables. These variables reflect the impacts of predetermined fuel prices and federal fuel economy standards. Therefore, the resulting model should not be used by itself to estimate the long-run effects of fuel price changes on fuel consumption because it does not represent the long-run effect of fuel prices on vehicle fuel economy. 
Current fuel price may affect current year vehicle efficiency through driving behavior and maintenance practices. For example, when fuel prices increase, motorists may choose to drive more slowly to conserve fuel. While acknowledging that such behavior almost certainly does occur, the potential effects on fuel economy are on the order of a few percent. However, there is a potential countervailing effect. If, when fuel prices rise, motorists are most likely to reduce total travel by cutting back on long-distance travel, the effect on average fuel economy could be perverse. It is well known that fuel economy tends to increase with trip length (Murrell, 1980). On short trips a larger fraction of miles are likely to be traveled when a vehicle's engine is not fully warmed up, and is therefore considerably less fuel efficient. In addition, short trips are more likely to involve stop-and-go driving rather than more efficient highway cruising. ${ }^{8}$ It is therefore an empirical matter whether factors tending to increase or decrease fuel economy dominate.

The estimated MPG elasticities of current fuel cost, as will be seen below, range from about -0.05 to -0.10 , indicating that current fuel cost has a negative effect on fuel economy. The lower end of this range seems plausible, the upper end a bit too high. Fortunately, coefficient estimates for other variables are little affected by the inclusion or exclusion of fuel cost, with the exception of the CAFE variable, whose coefficient dropped from 0.5 without fuel cost, to 0.4 when it was included. (The CAFE variable is not the respective fuel economy standard for the year in which a vehicle was produced, but rather the average fuel economy of all passenger cars or light trucks, as appropriate, sold in that year.) The adjusted $R^{2}$ of the MPG equation is also virtually unaffected by whether LCOST is included. Nonetheless, we include it in all models for the sake of completeness and symmetry.

\subsubsection{Estimation Sample Results}

We used the estimation half of the sample to test the significance of the variables listed in equations (12) and to test the hypothesis that motorists respond symmetrically to changes in MPG or fuel price. The three equations were estimated by 3SLS using the LIMDEP (Greene, 1995) econometric software. Under symmetry, vehicle use should respond equivalently to a change in the fuel cost per mile of travel of whether the change was caused by a one percent increase in fuel economy or a one percent decrease in fuel price. The test is carried out by constraining the coefficients (elasticities) of fuel price and MPG to be equal in magnitude and opposite in sign. The cost-per-mile symmetry constraint was not rejected at the 0.05 level, based on a Wald test with significance level of 0.28 . All variables in the vehicle use (LMI) and fuel economy (MPG) equations were

${ }^{8}$ Assuming a $55 \% / 45 \%$ split for city and highway travel and 40 percent better fuel economy in highway travel, even if all of the reduction in travel resulting from a fuel price increase were assumed to be highway travel, a ten percent price increase would produce a two percent reduction in total travel, a 3.6 percent drop in highway travel and about a 0.3 percent reduction in fuel economy, for an approximate elasticity of only -.03 . 
statistically significant at the 0.05 level. In the fuel cost equation, neither vehicle miles nor MPG are significant at the 0.05 level, suggesting that the price paid for fuel by one vehicle households may be independent of usage or MPG.

While significance levels based on the full sample may not be valid, still coefficent estimates based on the full sample should have the lowest variance. For this reason, we present full sample constrained estimates in Table 6 . Overall, the vehicle miles equation has a fairly low adjusted $\mathrm{R}^{2}$ of 0.29 , which is not unusual for regressions fitted to household data. ${ }^{9}$ All coefficient estimates have the expected signs and reasonable magnitudes. The elasticities of fuel cost and MPG, which have been constrained to be equal and opposite in sign, are -0.29 and +0.29 , respectively. These are not the full system elasticities, since they pertain to only the vehicle use equation. The full system elasticities will not differ by much, however, as will be explained in detail below. The elasticity with respect to vehicle age is -0.20 , implying that an 11 -year-old vehicle will be used only about two percent less than a ten-year-old vehicle. The elasticity with respect to income is quite small, only about +0.1 . In part, this may be due to the relatively poor measure of income available in the RTECS data. Other coefficient estimates indicate that vehicle use increases with household size, that vehicles used on the job are driven more than those strictly for household use, and that light trucks receive slightly more usage than other vehicle types.

The most important variables in the fuel cost equation are the national average price of gasoline and the grade of fuel bought. The adjusted $\mathrm{R}^{2}$ is the highest of all three equations at 0.93 . The most important variables in the MPG equation are the number of cylinders of the vehicle's engine and the average MPG of all cars or light trucks (as the case may be) sold in the same model year as the car or truck in question. Vehicle use also has a significant and positive effect on MPG. Fuel economy improves about one percent for every ten percent increase in VMT. The elasticity of MPG with respect to current fuel price is -0.09 suggesting that higher fuel prices tend to slightly lower the fuel economy of a given vehicle. The adjusted $R^{2}$ is 0.68 .

\subsubsection{System Elasticity of MPG}

In the three-equation system, the effects of an exogenous change in MPG on vehicle use involve both the vehicle use and fuel price equations. We can solve for the total system elasticity of MPG by substituting equation (1c) for price in equation (1a) and collecting terms. Carrying out these manipulations leads to the following equation for miles as a

${ }^{9}$ It should serve as a warning, however, that most of the determinants of household vehicle use are omitted and, if they are correlated with included variables, could therefore bias coefficient estimates. Treating the key variable miles, cost and MPG as endogenous is one way to minimize this problem. 
Table 6. One-Vehicle Households

\begin{tabular}{|c|c|c|c|c|}
\hline Variable Name & $\begin{array}{l}\text { Coefficient } \\
\text { Estimate }\end{array}$ & Standard Error & $\begin{array}{l}\text { Significance } \\
\text { Level }\end{array}$ & Mean \\
\hline \multicolumn{5}{|c|}{ LMI } \\
\hline Constant & 7.534 & 0.181 & 0.000 & \\
\hline LAGE & -0.207 & $0.163 \mathrm{E}-01$ & 0.000 & 1.918 \\
\hline LCOST & -0.286 & $0.279 E-01$ & 0.000 & 0.366 \\
\hline LMPG & 0.286 & $0.279 \mathrm{E}-01$ & 0.000 & 2.858 \\
\hline LINC & $0.924 \mathrm{E}-01$ & $0.147 \mathrm{E}-01$ & 0.000 & 9.916 \\
\hline LHH & 0.178 & $0.171 \mathrm{E}-01$ & 0.000 & 0.611 \\
\hline LVEHS & 0.667 & $0.297 \mathrm{E}-01$ & 0.000 & $-0.312 \mathrm{E}-01$ \\
\hline JOB & 0.280 & $0.237 \mathrm{E}-01$ & 0.000 & 0.258 \\
\hline TRUCK & 0.167 & $0.293 \mathrm{E}-01$ & 0.000 & 0.127 \\
\hline $\begin{array}{l}\text { Adjusted } R^{2}=0.295 \\
\text { Wald test } X^{2}=0.308\end{array}$ & \multicolumn{2}{|c|}{$\begin{array}{l}\text { Number of observations }=4,270 \\
\text { Significance level }=0.579\end{array}$} & \multicolumn{2}{|c|}{ Dependent Variable Mean $=8.946$} \\
\hline \multicolumn{5}{|c|}{. LCOST } \\
\hline Constant & -4.353 & $0.323 \mathrm{E}-01$ & 0.000 & \\
\hline LMI & $0.752 \mathrm{E}-04$ & $0.244 \mathrm{E}-02$ & 0.975 & 8.946 \\
\hline LMPG & $0.414 \mathrm{E}-02$ & $0.385 E-02$ & 0.282 & 2.858 \\
\hline LEAD & $-0.518 \mathrm{E}-01$ & $0.260 \mathrm{E}-02$ & 0.000 & 0.171 \\
\hline OCT & 0.113 & $0.204 \mathrm{E}-02$ & 0.000 & 0.250 \\
\hline SOUTH & $-0.321 \mathrm{E}-01$ & $0.210 \mathrm{E}-02$ & 0.000 & 0.319 \\
\hline NCENT & $-0.161 E-01$ & $0.225 E-02$ & 0.000 & 0.243 \\
\hline NECC & $0.164 \mathrm{E}-01$ & $0.334 \mathrm{E}-02$ & 0.000 & $0.808 \mathrm{E}-01$ \\
\hline LEIAPR & 0.945 & $0.479 \mathrm{E}-02$ & 0.000 & 4.973 \\
\hline Adjusted $\mathrm{R}^{2}=0.920$ & \multicolumn{2}{|c|}{ Number of observations $=4,270$} & \multicolumn{2}{|c|}{ Dependent Variable Mean $=0.366$} \\
\hline \multicolumn{5}{|c|}{ LMPG } \\
\hline Constant & 1.902 & $0.845 \mathrm{E}-01$ & 0.000 & \\
\hline LMI & $0.613 \mathrm{E}-01$ & $0.924 \mathrm{E}-02$ & 0.000 & 8.946 \\
\hline LCOST & $-0.878 \mathrm{E}-01$ & $0.183 \mathrm{E}-01$ & 0.000 & 0.366 \\
\hline LCAFE & 0.494 & $0.170 \mathrm{E}-01$ & 0.000 & 3.054 \\
\hline LCYL & -0.605 & $0.120 \mathrm{E}-01$ & 0.000 & 1.760 \\
\hline TRUCK & $-0.355 \mathrm{E}-01$ & $0.105 \mathrm{E}-01$ & 0.001 & 0.127 \\
\hline Adjusted $R^{2}=0.677$ & \multicolumn{2}{|c|}{ Number of observations $=4,270$} & \multicolumn{2}{|c|}{ Dependent Variable Mean $=2.858$} \\
\hline
\end{tabular}

function of MPG, where exogenous variables and constant terms are represented by the term $\mathrm{K}$.

$$
M I=K \cdot M P G^{\frac{a_{2} b_{2}-1}{1-a_{2} b_{1}}}=K \cdot M P G^{\beta}
$$


From equation (13) it is evident that the total elasticity of MPG is a function of the single equation elasticities of vehicle use with respect to price (and MPG since $a_{3}=-a_{2}$ ), as well as the elasticities of price with respect to both miles traveled and MPG. Inspection of equation (13) reveals that if $b_{1}$ and $b_{2}$ are both $<<1$, then the system elasticity of vehicle use with respect to vehicle efficiency will be very close to $-a_{2}$. This turns out to be the case in the one-vehicle household system. The partial elasticity of vehicle use with respect to MPG is +0.29. Plugging the other coefficient estimates into equation (13) produces a system elasticity estimate of +0.28 . Thus, for one-vehicle households, these results suggest a rebound effect of 28 percent: a ten percent increase in fuel economy, other things constant will produce a 2.8 percent increase in vehicle use. This system elasticity should be interpreted as a long-run rebound effect, since the data consist of different households in different circumstances and span a 15-year time interval from 1979 to 1994, with the caveat that the impact of fuel prices on the number of vehicles a household owns is not included.

\subsection{TWO-VEHICLE HOUSEHOLDS}

The two-vehicle household model comprises six equations, a three-equation system for each vehicle. A notable difference from the one-vehicle household system is that we add to the vehicle use equation the annual miles of the other vehicle as another simultaneous, endogenous variable. Miles traveled by the other vehicle reflect the nonlinearity in the household's production of the quantity of transportation services and thereby reflect the influence of the other vehicle's characteristics. A given household appears twice in this database. In the second record, the vehicle listed as vehicle number one becomes vehicle number two and the previous vehicle two becomes vehicle one. As a result, the two sets of three equations will have identical coefficient estimates, and so it is sufficient to list only one three-equation set. Once again, half of the sample was used for exploratory analysis of alternative equation formulations, the other half for hypothesis testing, but the coefficient estimates presented in Table 7 are based on the full sample. The cost-per-mile symmetry constraint could not be rejected, with a significance level of 0.66 . All variables were statistically significant except for MPG in the cost equation. Once again, only the constrained results are presented in Table 7.

\subsubsection{Miles}

The $\mathrm{R}^{2}$ value of 0.40 for the LMI equation is better than that of the one-vehicle household model because of the addition of the DAYS variable in this model. Since this variable was not collected in the 1979-81 survey, none of that survey data can be used in estimating the 2-vehicle household model. DAYS is introduced because average vehicle ownership (VEHS), which is used in the one-vehicle household model, does not distinguish between vehicles one and two. 
Table 7. Two-Vehicle Households

\begin{tabular}{|c|c|c|c|c|}
\hline Variable Name & $\begin{array}{l}\text { Coefficient } \\
\text { Estimate }\end{array}$ & Standard Error & $\begin{array}{l}\text { Significance } \\
\text { Level }\end{array}$ & Mean \\
\hline \multicolumn{5}{|c|}{ LMII } \\
\hline Constant & 3.586 & 0.139 & 0.000 & \\
\hline LAGEI & -0.228 & $0.866 \mathrm{E}-02$ & 0.000 & 1.852 \\
\hline LCOSTl & -0.280 & $0.169 \mathrm{E}-01$ & 0.000 & 0.338 \\
\hline LMPG 1 & 0.280 & $0.169 \mathrm{E}-01$ & 0.000 & 2.873 \\
\hline LINC & $0.669 E-01$ & $0.924 \mathrm{E}-02$ & 0.000 & 10.40 \\
\hline LHH & 0.230 & $0.130 \mathrm{E}-01$ & 0.000 & 0.960 \\
\hline LDAYI & 0.897 & $0.132 \mathrm{E}-01$ & 0.000 & 5.738 \\
\hline SOUTH & $0.636 \mathrm{E}-01$ & $0.126 \mathrm{E}-01$ & 0.000 & 0.313 \\
\hline LMI2 & -0.114 & $0.127 \mathrm{E}-01$ & 0.000 & 8.938 \\
\hline $\begin{array}{l}\text { Adjusted } R^{2}=0.414 \\
\text { Wald test } X^{2}=2.100\end{array}$ & \multicolumn{2}{|c|}{$\begin{array}{l}\text { Number of observations }=10,204 \\
\text { Significance level }=0.350\end{array}$} & \multicolumn{2}{|c|}{ Dependent Variable Mean $=8.938$} \\
\hline \multicolumn{5}{|c|}{ LCOSTl } \\
\hline Constant & -4.511 & $0.161 \mathrm{E}-01$ & 0.000 & \\
\hline LMI1 & $0.467 \mathrm{E}-02$ & $0.831 E-03$ & 0.000 & 8.938 \\
\hline LMPG1 & $0.670 \mathrm{E}-03$ & $0.156 \mathrm{E}-02$ & 0.667 & 2.873 \\
\hline LEAD1 & $-0.468 \mathrm{E}-01$ & $0.117 \mathrm{E}-02$ & 0.000 & 0.179 \\
\hline PREMI & 0.118 & $0.106 \mathrm{E}-02$ & 0.000 & 0.174 \\
\hline MID1 & 0.110 & $0.171 E-02$ & 0.000 & $0.605 E-01$ \\
\hline SOUTH & $-0.246 \mathrm{E}-01$ & $0.101 \mathrm{E}-02$ & 0.000 & 0.313 \\
\hline LELAPR & 0.969 & $0.272 \mathrm{E}-02$ & 0.000 & 4.947 \\
\hline NECC & $0.194 E-01$ & $0.236 \mathrm{E}-02$ & 0.000 & $0.410 \mathrm{E}-01$ \\
\hline Adjusted $\mathrm{R}^{2}=0.931$ & \multicolumn{2}{|c|}{ Number of observations $=10,204$} & \multicolumn{2}{|c|}{ Dependent Variable Mean $=0.338$} \\
\hline \multicolumn{5}{|c|}{ LMPG1 } \\
\hline Constant & 2.087 & $0.466 \mathrm{E}-01$ & 0.000 & \\
\hline LMI 1 & $0.201 E-01$ & $0.443 E-02$ & 0.000 & 8.938 \\
\hline LCOST1 & $-0.448 \mathrm{E}-01$ & $0.127 \mathrm{E}-01$ & 0.000 & 0.338 \\
\hline LCYLI & -0.554 & $0.825 E-02$ & 0.000 & 1.756 \\
\hline TRANS1 & -0.109 & $0.501 E-02$ & 0.000 & 0.721 \\
\hline LCAFE 1 & 0.554 & $0.109 \mathrm{E}-01$ & 0.000 & 3.052 \\
\hline TRUCK1 & $-0.651 \mathrm{E}-01$ & $0.541 E-02$ & 0.000 & 0.261 \\
\hline Adjusted $R^{2}=0.676$ & \multicolumn{2}{|c|}{ Number of observations $=10,204$} & \multicolumn{2}{|c|}{ Dependent Variable Mean $=2.873$} \\
\hline
\end{tabular}

The fuel cost-per-mile partial elasticity of travel estimate is virtually identical to that of the one-vehicle model: -0.28 . Vehicle use is even less income elastic than in the onevehicle household model +0.067 here versus +0.092 in the single vehicle household model. It is not clear, however, whether this reflects a real phenomenon or is a result of deficiencies in the measurement of income. As we have noted above, the income data in RTECs are grouped. The highest income category cut-off varies from survey to survey 
from as low as $\$ 35,000$ in 1985 to $\$ 100,000$ in 1994 (both current dollars). As vehicle ownership increases, the distribution of household incomes shifts upwards. As more households fall into the upper category, information about incomes disappears. Thus, part if not all of the reduction in income elasticity as vehicle ownership increases may be an artifact of the measurement of income. Vehicle use decreases with age at about the same rate as for one-vehicle households, and increases with household size. The correlation between vehicle use and the number of days the household owned the vehicle in the survey year is 0.9 .

Fuel economy is not statistically significant in the fuel cost equation, but miles traveled is. Unlike the one-vehicle household equation system, here increased miles apparently lead to higher fuel costs per gallon. Once again, number of cylinders and model-year average MPG are the most important variables in the MPG equations. $R^{2}$ values for these ' two equations are very similar to those of the one-vehicle household model.

The system elasticity of fuel economy for two-vehicle households differs from that for one-vehicle households because the use of one vehicle affects that of the other. Thus, if a fuel economy improvement in vehicle one increases its annual use, this will cause the usage of vehicle two to decrease somewhat.

The effect of simultaneous determination of vehicle usage on the rebound effect can be approximated by a two-equation model in which the effects of all other factors are represented by two constants, $\mathrm{K}_{1}$ and $\mathrm{K}_{2}$.

$$
\begin{aligned}
& M_{1}=K_{1} M_{2}^{\alpha} \\
& M_{2}=K_{2} M_{1}^{\gamma}
\end{aligned}
$$

Assume that an exogenous change in the fuel economy of vehicle one occurs, such that $K_{1}$ increases by a multiplicative factor $1+r$, where $0<r<1$. The change in $M_{1}$ will cause $\mathrm{M}_{2}$ to increase by a multiplicative factor of $(1+r)^{\gamma}$. But this change in $\mathrm{M}_{2}$ will induce a corresponding change in $M_{1}$ of $(1+r)^{\alpha \gamma}$. By continuing to iterate this process, it can be shown that the ultimate effect of the $(1+r)$ increase in $K_{1}$ is to increase $M_{1}$ by a factor of $(1+r)^{\Phi}$, where,

$$
\Phi=\sum_{i=0}^{\infty}(\alpha \gamma)^{i}
$$

This is clearly an infinite geometric series which will converge to $1 /(1-\alpha \gamma)$ provided that $|\alpha \gamma|<1$. In this case $\alpha=\gamma=-0.1137$, so that the ultimate change in $M_{1}$ will be $(1+r)^{1.013}$, which is so close to $(1+r)$ that it can be ignored for practical purposes. By a similar line 
of reasoning it can be shown that the ultimate elasticity of $\mathrm{M}_{2}$ with respect to a change in $\mathrm{M}_{1}$ is $\gamma /(1-\alpha \gamma)=1.013 \gamma$.

The effect of a change in the fuel economy of vehicle one on total household vehicle miles is the sum of the changes in the use of both vehicles. If the own system elasticity of MPG is $\beta$, then the household system elasticity will be,

$$
\mathrm{B}=\frac{\beta(1+\gamma)}{1-\alpha \gamma}
$$

Plugging the coefficients from Table 7 into equation (16) results in an overall estimate of the rebound effect that is about ten percent smaller than the partial elasticity of +0.28 . The same principles apply to calculating elasticities for three-, four-, and five-vehicle households although the equations are somewhat more complex.

\subsection{THREE-VEHICLE HOUSEHOLDS}

In the three-vehicle household model, the usage of two other vehicles affects each vehicle's own use. Each vehicle's use must be entered as a separate variable since the sum would not be recognized by the 3SLS estimation method as an endogenous variable.

The result is a nine-equation system with three blocks of three, three-equation subsystems for each vehicle. Again, due to the construction of the database, each of the subsystems will be identical.

The three-vehicle household sample was also split into two halves for formulating and testing hypotheses about the vehicle use model. Each half sample, however, contained only about 3,500 vehicle records, or roughly 1,200 households. Once again, the hypothesis of fuel price and MPG elasticity symmetry could not be rejected with a significance level of $0.45 .^{10}$ Perhaps due in part to the smaller sample size, several variables were not significant at the 0.05 level. In the vehicle miles equation income was significant at the 0.06 level. In the cost equation vehicle miles was significant at the 0.10 level, MPG at 0.58 . The significance level of vehicle miles in the MPG equation was 0.11 . Results of estimation on the full sample are shown in Table 8, again for the constrained model.

${ }^{10}$ The reader may note that the hypothesis of symmetry would have been rejected at the 0.05 level had we tested it on the full sample, as shown in Table 8, instead of on the "estimation" half. 
Table 8. Three-Vehicle Households

\begin{tabular}{|c|c|c|c|c|}
\hline Variable Name & $\begin{array}{l}\text { Coefficient } \\
\text { Estimate }\end{array}$ & Standard Error & $\begin{array}{l}\text { Significance } \\
\text { Level }\end{array}$ & Mean \\
\hline \multicolumn{5}{|c|}{ LMII } \\
\hline Constant & 3.775 & 0.176 & 0.000 & \\
\hline LAGE1 & -0.231 & $0.890 \mathrm{E}-02$ & 0.000 & 1.830 \\
\hline LCOST1 & -0.193 & $0.211 \mathrm{E}-01$ & 0.000 & 0.340 \\
\hline LMPG1 & 0.193 & $0.211 \mathrm{E}-01$ & 0.000 & 2.855 \\
\hline LDAY1 & 0.934 & $0.112 \mathrm{E}-01$ & 0.000 & 5.560 \\
\hline LINC & $0.339 \mathrm{E}-01$ & $0.110 \mathrm{E}-01$ & 0.002 & 10.56 \\
\hline LHH & 0.169 & $0.161 E-01$ & 0.000 & 1.074 \\
\hline JOB 1 & 0.190 & $0.148 \mathrm{E}-01$ & 0.000 & 0.305 \\
\hline LMI2 & $-0.535 E-01$ & $0.111 \mathrm{E}-01$ & 0.000 & 8.767 \\
\hline LMI3 & $-0.445 \mathrm{E}-01$ & $0.112 \mathrm{E}-01$ & 0.000 & 8.767 \\
\hline $\begin{array}{l}\text { Adjusted } R^{2}=0.522 \\
\text { Wald test } X^{2}=9.770\end{array}$ & \multicolumn{2}{|c|}{$\begin{array}{l}\text { Number of observations }=7,773 \\
\text { Significance level }=0.021\end{array}$} & \multicolumn{2}{|c|}{ Dependent Variable Mean $=8.767$} \\
\hline \multicolumn{5}{|c|}{ LCOST1 } \\
\hline Constant & -4.542 & $0.169 \mathrm{E}-01$ & 0.000 & \\
\hline LMI1 & $0.220 \mathrm{E}-02$ & $0.712 \mathrm{E}-03$ & 0.002 & 8.767 \\
\hline LMPG1 & $-0.363 \mathrm{E}-03$ & $0.170 \mathrm{E}-02$ & 0.831 & 2.855 \\
\hline LEAD1 & $-0.488 \mathrm{E}-01$ & $0.126 \mathrm{E}-02$ & 0.000 & 0.195 \\
\hline ОСТ01 & 0.117 & $0.106 \mathrm{E}-02$ & 0.000 & 0.224 \\
\hline NEAST & $0.268 \mathrm{E}-01$ & $0.132 \mathrm{E}-02$ & 0.000 & 0.183 \\
\hline LEIAPR & 0.978 & $0.298 \mathrm{E}-02$ & 0.000 & 4.952 \\
\hline Adjusted $\mathrm{R}^{2}=0.935$ & \multicolumn{2}{|c|}{ Number of observations $=7,773$} & \multicolumn{2}{|c|}{ Dependent Variable Mean $=0.340$} \\
\hline \multicolumn{5}{|c|}{ LMPG1 } \\
\hline Constant & 2.621 & $0.693 \mathrm{E}-01$ & 0.000 & \\
\hline LAGE1 & $-0.379 \mathrm{E}-01$ & $0.440 \mathrm{E}-02$ & 0.000 & 1.830 \\
\hline LMIl & $0.155 \mathrm{E}-01$ & $0.390 \mathrm{E}-02$ & 0.000 & 8.767 \\
\hline LCOsT1 & $-0.861 \mathrm{E}-01$ & $0.165 \mathrm{E}-01$ & 0.000 & 0.340 \\
\hline LCYL1 & -0.561 & $0.948 \mathrm{E}-02$ & 0.000 & 1.769 \\
\hline LCAFE1 & 0.425 & $0.165 \mathrm{E}-01$ & 0.000 & 3.035 \\
\hline TRANS1 & -0.103 & $0.573 \mathrm{E}-02$ & 0.000 & 0.697 \\
\hline TRUCKI & -0.101 & $0.663 \mathrm{E}-02$ & 0.000 & 0.299 \\
\hline Adjusted $\mathrm{R}^{2}=0.661$ & \multicolumn{2}{|c|}{ Number of observations $=7,773$} & \multicolumn{2}{|c|}{ Dependent Variable Mean $=2.855$} \\
\hline
\end{tabular}

\subsubsection{System Elasticities}

Vehicle use in three-vehicle households appears to be less elastic with respect to fuel cost-per-mile than in one- or two-vehicle households. The partial elasticity of vehicle miles with respect to own MPG is 0.19 . These partial elasticities overlook the feedback routes by which changes in a vehicle's own fuel cost-per-mile indirectly affect its use. 
Although the algebra is more tedious than for two-vehicle households, computation of the system elasticities follows the same principles.

Given the coefficient values in Table 8, the total feedback effects can be shown to be on the order of ten percent of the partial elasticity of 0.19 . The full system elasticity of vehicle use with respect to its own fuel cost per mile is -0.175 , whereas the partial elasticity is -0.193 . These vehicle interaction effects confirm that households will adjust patterns of vehicle use in response to changes in the cost of fuel, but the adjustments will be small. Such small but statistically significant shifts among vehicles were also reported by Greene and $\mathrm{Hu}$ (1984). Thus, the total household vehicle travel elasticity of fuel costper-mile is less than the system elasticity for any given vehicle due to the interdependencies among vehicles.

\subsection{FOUR-AND FIVE-VEHICLE HOUSEHOLDS}

As the numbers of vehicles per household increases, the RTECS sample sizes continue to shrink as the number of simultaneous equations and coefficients to be estimated increase. The five-vehicle household model exceeded LIMDEP's size limits for estimation by 3SLS. For this reason, we simplified the five-vehicle model structure by assuming that we could represent fuel costs by fuel cost-per-mile. Because fuel cost and MPG no longer enter independently, there are only two simultaneous equations for each vehicle: miles and cost-per-mile. The five-vehicle household model thus becomes a ten-equation system. Given what had been learned previously about the form of multi-vehicle household models, we did not divide the four- or five-vehicle household samples in half for exploration and hypothesis testing but rather went straight to hypothesis testing with the full sample. Results of estimating these models by means of 3SLS are shown in Tables 9 and 10 .

Once again we find that the hypothesis that the elasticities of fuel price and fuel economy are equal and opposite in sign is not rejected for four-vehicle households. Travel by other vehicles is generally not statistically significant, however. Household income is insignificant in the four-vehicle household model. With the average income of fourvehicle households at $\$ 52,000$, a very large number of households fall into the upper income category of the RTECS databases, making the income variable a rather poor measure of true household income. Income is deleted from the five-vehicle household model because average incomes are higher still.

The partial fuel cost-per-mile elasticity for four-vehicle households is -0.24 . When the full system effects are considered, this drops to -0.22 . Other coefficients are similar in magnitude and sign to those of one-, two- and three-vehicle household models. 
Table 9. Four-Vehicle Households Includes Income

\begin{tabular}{|c|c|c|c|c|}
\hline Variable Name & $\begin{array}{l}\text { Coefficient } \\
\text { Estimate }\end{array}$ & Standard Error & $\begin{array}{l}\text { Significance } \\
\text { Level }\end{array}$ & Mean \\
\hline \multicolumn{5}{|c|}{ LMII } \\
\hline Constant & 3.645 & 0.256 & 0.000 & \\
\hline LAGEI & -0.259 & $0.123 E-01$ & 0.000 & 1.853 \\
\hline LCOST1 & -0.239 & $0.292 \mathrm{E}-01$ & 0.000 & 0.345 \\
\hline LMPG 1 & 0.239 & $0.292 \mathrm{E}-01$ & 0.000 & 2.856 \\
\hline LINC & $0.856 \mathrm{E}-02$ & $0.164 \mathrm{E}-01$ & 0.602 & 10.70 \\
\hline $\mathrm{LHH}$ & 0.136 & $0.248 \mathrm{E}-01$ & 0.000 & 1.224 \\
\hline LDAY1 & 0.921 & $0.150 \mathrm{E}-01$ & 0.000 & 5.513 \\
\hline JOB 1 & 0.212 & $0.212 \mathrm{E}-01$ & 0.000 & 0.306 \\
\hline LMI2 & $-0.115 \mathrm{E}-01$ & $0.149 \mathrm{E}-01$ & 0.440 & 8.709 \\
\hline LMI3 & $-0.237 \mathrm{E}-01$ & $0.149 \mathrm{E}-01$ & 0.112 & 8.709 \\
\hline LMI4 & $-0.254 \mathrm{E}-01$ & $0.149 \mathrm{E}-01$ & 0.088 & 8.709 \\
\hline $\begin{array}{l}\text { Adjusted } R^{2}=0.552 \\
\text { Wald test } X^{2}=4.580\end{array}$ & \multicolumn{2}{|c|}{$\begin{array}{l}\text { Number of observations }=3,756 \\
\text { Significance level }=0.333\end{array}$} & \multicolumn{2}{|c|}{ Dependent Variable Mean $=8.709$} \\
\hline \multicolumn{5}{|c|}{ LCOST1 } \\
\hline Constant & -4.575 & $0.246 \mathrm{E}-01$ & 0.000 & \\
\hline LMPG1 & $0.465 \mathrm{E}-02$ & $0.230 \mathrm{E}-02$ & 0.043 & 2.856 \\
\hline LMII & $0.262 \mathrm{E}-03$ & $0.971 \mathrm{E}-03$ & 0.787 & 8.709 \\
\hline LEAD1 & $-0.488 \mathrm{E}-01$ & $0.167 \mathrm{E}-02$ & 0.000 & 0.227 \\
\hline OCT01 & 0.111 & $0.150 \mathrm{E}-02$ & 0.000 & 0.213 \\
\hline LEIAPR & 0.985 & $0.439 \mathrm{E}-02$ & 0.000 & 4.961 \\
\hline Adjusted $\mathrm{R}^{2}=0.933$ & \multicolumn{2}{|c|}{ Number of observations $=3,756$} & \multicolumn{2}{|c|}{ Dependent Variable Mean $=0.345$} \\
\hline \multicolumn{5}{|c|}{ LMPG1 } \\
\hline Constant & 2.743 & 0.101 & 0.000 & \\
\hline LAGEl & $-0.471 \mathrm{E}-01$ & $0.639 \mathrm{E}-02$ & 0.000 & 1.853 \\
\hline LMI1 & $0.203 E-01$ & $0.559 E-02$ & 0.000 & 8.709 \\
\hline LCOSTI & $-0.963 \mathrm{E}-01$ & $0.238 \mathrm{E}-01$ & 0.000 & 0.345 \\
\hline LCYLSI & -0.580 & $0.138 \mathrm{E}-01$ & 0.000 & 1.767 \\
\hline LCAFEl & 0.389 & $0.238 \mathrm{E}-01$ & 0.000 & 3.021 \\
\hline TRANS1 & -0.103 & $0.821 E-02$ & 0.000 & 0.684 \\
\hline TRUCK1 & -0.108 & $0.967 \mathrm{E}-02$ & 0.000 & 0.287 \\
\hline Adjusted $\mathrm{R}^{2}=0.674$ & \multicolumn{2}{|c|}{ Number of observations $=3,756$} & \multicolumn{2}{|c|}{ Dependent Variable Mean $=2.856$} \\
\hline
\end{tabular}


Table 10. Five-Vehicle Households

\begin{tabular}{|c|c|c|c|c|}
\hline Variable Name & $\begin{array}{l}\text { Coefficient } \\
\text { Estimate }\end{array}$ & Standard Error & $\begin{array}{c}\text { Significance } \\
\text { Level }\end{array}$ & Mean \\
\hline \multicolumn{5}{|c|}{ LMI1 } \\
\hline Constant & 3.255 & 0.402 & 0.000 & \\
\hline LAGEI & -0.250 & $0.192 \mathrm{E}-01$ & 0.000 & 1.862 \\
\hline LCPM1 & -0.214 & $0.501 \mathrm{E}-01$ & 0.000 & -2.496 \\
\hline JOB1 & 0.158 & $0.349 \mathrm{E}-01$ & 0.000 & 0.305 \\
\hline LDAY1 & 0.977 & $0.242 \mathrm{E}-01$ & 0.000 & 5.464 \\
\hline LMI2 & $-0.124 \mathrm{E}-01$ & $0.233 E-01$ & 0.596 & 8.687 \\
\hline LMI3 & $0.171 \mathrm{E}-01$ & $0.230 \mathrm{E}-01$ & 0.456 & 8.687 \\
\hline LMI4 & $-0.414 \mathrm{E}-02$ & $0.230 \mathrm{E}-01$ & 0.857 & 8.687 \\
\hline LMI5 & $-0.341 \mathrm{E}-02$ & $0.231 \mathrm{E}-01$ & 0.883 & 8.687 \\
\hline \multicolumn{3}{|c|}{ Number of observations $=1,320$} & \multicolumn{2}{|c|}{ Dependent Variable Mean $=8.687$} \\
\hline \multicolumn{5}{|c|}{ LCPM1 } \\
\hline Constant & -6.910 & 0.244 & 0.000 & \\
\hline LMIl & $-0.377 \mathrm{E}-01$ & $0.926 \mathrm{E}-02$ & 0.000 & 8.687 \\
\hline OCT1 & 0.132 & $0.147 \mathrm{E}-01$ & 0.000 & 0.221 \\
\hline LCYLI & 0.550 & $0.242 \mathrm{E}-01$ & 0.000 & 1.778 \\
\hline LCAFEI & -0.462 & $0.308 \mathrm{E}-01$ & 0.000 & 3.022 \\
\hline TRANS1 & $0.885 \mathrm{E}-01$ & $0.145 E-01:$ & 0.000 & 0.687 \\
\hline TRUCKI & 0.102 & $0.150 \mathrm{E}-01$ & 0.000 & 0.289 \\
\hline LEIAPR & 1.017 & $0.371 E-01$ & 0.000 & 4.956 \\
\hline Adjusted $R^{2}=0.724$ & \multicolumn{2}{|c|}{ Number of observations $=1,320$} & \multicolumn{2}{|c|}{ Dependent Variable Mean $=2.496$} \\
\hline
\end{tabular}

The five-vehicle household model pushes the limits of the RTECS data. The usable sample size drops to 1,320 records after rejecting records with invalid or missing data. This represents only 264 households spread out over five survey years, or about 50 records per survey. Despite this, the results are generally consistent with those for households with fewer vehicles.

The estimated partial elasticity of vehicle use with respect to fuel cost-per-mile is -0.21 . Once again, the indirect effects equation are relatively small, so that the system elasticity is just a little smaller than the partial elasticity. The effects of other vehicles' travel are again non-significant.

\subsection{SUMMARY}

Combining all household level effects, estimates of the rebound effect of fuel economy on household vehicle travel range from +0.17 for 3 -vehicle households to +0.28 for one- 
vehicle households. The results suggest a trend of decreasing elasticity with level of vehicle ownership, but this is far from a definitive result.

Weighting the elasticities at each level of ownership by the distribution of households, numbers of vehicles per household, and average annual miles per vehicle produces an overall elasticity estimate of -0.23 for all household passenger cars and light trucks (Table 11). This compares well with the value of -0.22 estimated by Haughton and Sarkar (1996, p. 116) for total U.S. VMT using a time series of state data, as well as with recent estimates by Greene (1992). and Jones (1993) using U.S. national data, which range from -0.13 to -0.31 , depending on model formulation.

Table 11. Fuel Cost-per-Mile Elasticity of Vehicle Travel for All Vehicle Ownership Levels

\begin{tabular}{cccc}
\hline $\begin{array}{c}\text { Number of } \\
\text { Vehicles }\end{array}$ & $\begin{array}{c}\text { Distribution of } \\
\text { Households,1994 } \\
\text { RTEC Survey }\end{array}$ & $\begin{array}{c}\text { Average } \\
\text { Annual Miles } \\
\text { per Vehicle }\end{array}$ & $\begin{array}{c}\text { Household } \\
\text { Elasticity }\end{array}$ \\
\hline One & $18.5 \%$ & 8,434 & -0.28 \\
Two & $39.6 \%$ & 8,996 & -0.25 \\
Three & $24.7 \%$ & 9,095 & -0.17 \\
Four & $11.4 \%$ & 8,108 & -0.22 \\
Five & $5.8 \%$ & 7,766 & -0.21 \\
Total vehicle miles weighted average & & -0.23 \\
\hline
\end{tabular}




\section{CONCLUSIONS}

Estimates of the direct rebound effect obtained in this study using all six RTECS survey data bases confirm the recent results derived from aggregate national and state-level data: the direct, long-run rebound effect for light-duty motor vehicles in the United States is approximately +0.2 . The RTECS data are a particularly appropriate source of information on which to base such an assessment because of the care taken by the Energy Information Administration to accurately estimate vehicle miles from direct odometer readings and to accurately measure vehicle fuel economy. The fact that the surveys cover a period of fifteen years, during which there were large changes in vehicle prices and fuel economy is also reassuring. That this was a period of broadly but not exclusively declining fuel prices and improving fuel economy makes it especially appropriate for detecting the rebound effect.

Inferences about the rebound effect made in this paper do not include the potential effect of changes in fuel cost-per-mile on levels of vehicle ownership. If fuel economy improvements require a trade-off with vehicle price or other important attributes, the resulting change in vehicle ownership levels may well be negligible. Even if the fuel economy improvements were absolutely free, it is highly unlikely that the long-run rebound effect could be much larger than +0.3 , because fuel costs comprise on the order of ten percent of total vehicle ownership costs.

Recognizing the potential for simultaneous equations bias and using appropriate estimation methods proved to be crucial to obtaining meaningful results. When appropriate methods were used, the hypothesis that consumers will respond equivalently to a given change in fuel cost-per-mile, whether due to price changes or fuel economy changes, could not be rejected. In a certain respect, this result confirms the economically rational behavior of motorists. Most studies to date have simply assumed that the elasticities of vehicle travel with respect to fuel price and fuel economy were opposite in sign and equal in absolute value and have used cost-per-mile as to represent the combined effects of fuel price and fuel economy as a maintained hypothesis. Our findings provide strong empirical support for that practice.

Also, apparently for the first time, we have been able to successfully estimate reasonable vehicle use models for four- and five-vehicle households. As incomes rise and vehicle ownership levels increase, multi-vehicle households account for a growing percentage of U.S. households and more and more vehicle miles. The RTECS data suggest considerable similarity in the way households respond to fuel prices and fuel economy across ownership levels.

We consider this an extremely important result. Using household data and a simultaneous systems estimation method, we have obtained results that are very 
consistent with the consensus of recent studies based on aggregate national or state-level data. Therefore, we believe that policy-makers can be confident in an estimated value of the direct long-term rebound effect for vehicle travel of approximately +0.2 when fuel economy improvements come at a real cost and perhaps as much as +0.3 when they are costless. Conditional on the values of the indirect and general equilibrium rebound effects, this result confirms that technical efficiency improvements have an important.role to play in reducing carbon emissions from transportation. 


\section{REFERENCES}

1. Archibald, Robert and Robert Gillingham. 1980. "An Analysis of the Short-Run Consumer Demand for Gasoline Using Household Survey Data," Review of Economics and Statistics, vol. 62 (November), pp. 622-628.

2. Archibald, Robert and Robert Gillingham. 1981a. "The Distributional Impact of Alternative Gasoline Conservation Policies," Bell Journal of Economics, vol. 12, no. 2 (Autumn), pp. 426-444.

3. Archibald, Robert and Robert Gillingham. 1981b. "A Decomposition of the Price and Income Elasticities of the Consumer Demand for Gasoline," Southern Economic Journal, vol. 47, no. 4 (April), pp. 1021-1031.

4. Baltagi, B.H. and J.M. Griffin. 1984. "U.S. Gasoline Demand: What Next?" The Energy Journal, vol. 5, no. 1, pp. 129-140.

5. Becker, G.S. 1965. "A Theory of the Allocation of Time," The Economic Journal, vol. 75 , no. 299, pp. 493-517.

6. Blair, R.D., D.L. Kaserman, and R.C. Tepel. 1984. "The Impact of Improved Mileage on Gasoline Consumption," Economic Inquiry, vol. 22, pp. 209-217.

7. Bockstael, Nancy and Kenneth E. McConnell. 1981. "Theory and Estimation of Household Production Function for Wildlife Recreation," Journal of Environmental Economics and Management, vol. 8, pp. 199-214, September.

8. Bordley, R.F. 1993. "Estimating Automotive Elasticities From Segment Elasticities and First Choice/Second Choice Data," The Review of Economics and Statistics, vol. 75 , no. 3, pp. 455-462.

9. Brookes, L. 1990. "The Greenhouse Effect: The Fallacies in the Energy Efficiency Solution," Energy Policy, vol. 18, no. 2, pp. 199-201.

10. Chui, M.K. and W.E. McFarland. 1987. "The Value of Travel Time: New Estimates Developed Using a Speed Choice Model," Research Report 396-2F, Texas Transportation Institute, College Station, Texas.

11. Dahl, C.A. 1994. "Demand for Transportation Fuels: A Survey of Demand Elasticities and Their Components," manuscript, Division of Economics and Business, Colorado School of Mines.

12. Dahl, C.A. 1986. "Gasoline Demand Survey," The Energy Journal, vol. 7, no. 1, pp. 67-82.

13. Dahl, C.A. 1979. "Consumer Adjustment to a Gasoline Tax," The Review of Economics and Statistics, vol. 61, no. 3, pp. 427-432.

14. Dahl, C.A. and T. Sterner. 1991. "Analyzing Gasoline Demand Elasticities: A Survey," Energy Economics, vol. 13, no. 3, pp. 203-210.

15. Dargay, J. and D. Gately. 1994. "Oil Demand in the Industrialized Countries," The Energy Journal, vol. 15, special issue, pp. 39-67.

16. Davis, S.C. 1998. Transportation Energy Data Book Edition 18, ORNL-6941, Oak Ridge National Laboratory, Oak Ridge, Tennessee. 
17. Espey, M. 1996a. "Watching the Fuel Gauge: An International Model of Automobile Fuel Economy," Energy Economics, vol. 18, no. 1-2, pp. 93-106.

18. Espey, M. 1996b. "Explaining the Variation in Elasticity Estimates of Gasoline Demand in the United States: A Meta-Analysis," The Energy Journal, vol. 17, no. 3, pp. 49-60.

19. Gately, D. 1992. "Imperfect Price-Reversibility of U.S. Gasoline Demand: Asymmetric Responses to Price Increases and Declines," The Energy Journal, vol. 13, no. 4, pp. 179-207.

20. Gately, D. 1990. "The U.S. Demand for Highway Travel and Motor Fuel," The Energy Journal, vol. 11, no. 3, pp. 59-73.

21. Gately, D. 1988. "Taking Off: The U.S. Demand for Air Travel and Jet Fuel," The Energy Journal, vol. 9, no. 4, pp. 63-91.

22. Goldberg, P.K. 1996.. "The Effects of the Corporate Average Fuel Efficiency Standards," Working Paper 5673, National Bureau of Economic Research, Cambridge, MA.

23. Golob, T.F., S. Kim, and W. Ren. 1996. "How Households Use Different Types of Vehicles: A Structural Driver Allocation and Usage Model," Transportation Research $A$, vol. 30, no. 2, pp. 103-118.

24. Goodwin, P.B. 1992. "A Review of New Demand Elasticities with Special Reference to Short- and Long-Run Effects of Price Changes," Journal of Transport Economics and Policy, vol. 26, no. 2, pp. 155-170.

25. Greene, W.H., 1993. Ecnometric Analysis: Second Edition, Prentice Hall, Englewood Cliffs, New Jersey.

26. Greene, W.H., 1995. LIMDEP Version 7.0, Econometric Software, Inc., Plainview, N.Y.

27. Greene, D.L. 1992. "Vehicle Use and Fuel-Economy: How Big Is the 'Rebound' Effect?" The Energy Journal, vol. 13, no. 1, pp. 117-143.

28. Greene, D.L. 1990. "CAFE or PRICE: An Analysis of the Effects of Federal Fuel Economy Regulations and Gasoline Price on New Car MPG, 1978-89," The Energy Journal, vol. 11, no. 3, pp. 37-57.

29. Greene, D.L. 1984. "A Derived Demand Model of Regional Highway Diesel Fuel Use," Transportation Research B, vol. 18B, no. 1, pp. 43-61.

30. Greene, D.L. and P.S. Hu. 1984. "The Influence of the Price of Gasoline on Vehicle Use in Multivehicle Households," Transportation Research Record 988, Transportation Research Board, Washington, DC, pp. 19-23.

31. Greening, L.A. and D.L. Greene. 1997. "Energy Use, Technical Efficiency, and the Rebound Effect: A Review of the Literature," report to the Office of Policy Analysis and International Affairs, U.S. Department of Energy, Washington, DC, December.

32. Greening, L.A. and L. Schipper. 1994. "Incidence of a Carbon Tax on Gasoline and the Distribution of Greenhouse Gas Emissions Reductions Across Socioeconomic Groups in the Southeastern United States," Working Paper WP-94-05, College of Commerce and Business Administration, University of Alabama, Tuscaloosa, Alabama. 
33. Greening, L.A., H.T. Jeng, J. Formby, and D.C. Cheng. 1994. "Use of Region, LifeCycle, and Role Variables in the Short-Run Estimation of the Demand for Gasoline and Miles Traveled," Working Paper WP-94001, Division of Research and Service, College of Commerce and Business Administration, University of Alabama, Tuscaloosa, Alabama.

34. Grubb, M.J. 1990. "Energy Efficiency and Economic Fallacies," vol. 18, no. 8, pp. 783-785.

35. Haughton, J. and S. Sarker. 1996. "Gasoline Tax as a Corrective Tax: Estimates for the United States, 1970-1991," The Energy Journal, vol. 17, no. 2, pp. 103-126.

36. Heavenrich, R.M. and K.H. Hellman. 1996. Light-Duty Automotive Technology and Fuel Economy Trends Through 1996, EPA/AA/TDSG/96-01, U.S. Environmental Protection Agency, Office of Mobile Sources, Ann Arbor, Michigan.

37. Henderson, J.M. and R.E. Quandt. 1971. Microeconomic Theory: A Mathematical Approach, McGraw-Hill, New York.

38. Hensher. 1997. "Behavioral Value of Travel Time Savings in Personal and Commercial Automobile Travel," pp. 245-280 in Greene, D.L., D.W. Jones, and M.A. Delucchi, eds., The Full Costs and Benefits of Transportation, Springer, Heidelberg.

39. Hensher, D.A. and N.C. Smith. 1986. "A Structural Model of the Use of Automobiles by Households: A Case Study of Urban Australia," Transport Reviews, vol. 6 , no. 1, pp. 87-111

40. Hensher, D.A., F.W. Milthorpe, and N.C. Smith. 1990. "The Demand for Vehicle Use in the Urban Household Sector," Journal of Transport Economics and Policy, vol. 24, no. 2, pp. 119-137.

41. Hirst, E. and D. White. 1987. Indoor Temperature Changes After Retrofit: Inferences Based on Electricity Billing Data for Nonparticipants in the BPA Residential Weatherization Program, ORNL/CON-182, Oak Ridge National Laboratory, Oak Ridge, Tennessee.

42. Ippolito, R.A. 1981. "Estimating Airline Demand with Quality of Service Variables," Journal of Transport Economics and Policy, vol. 15, no. 1, pp. 7-15.

43. Jones, C.T. 1993. "Another Look at U.S. Passenger Vehicle Use and the 'Rebound' Effect from Improved Fuel Efficiency," The Energy Journal, vol. 14, no. 4, pp. 99110.

44. Kahn, James R. and W. Michael Kemp. 1985. "Economic Losses Associated with the Degradation of an Ecosystem: The Case of Submerged Aquatic Vegetation in the Chesapeake Bay," Journal of Environmental Economics and Management, vol. 12, pp. 246-263, September.

45. Khazzoom, J.D. 1997. "Impact of Pay-at-the-Pump on Safety Through Enhanced Vehicle Fuel Efficiency," The Energy Journal, vol. 18, no. 3, pp. 103-133.

46. Khazzoom, J.D. 1980. "Economic Implications of Mandated Efficiency in Standards for Household Appliances," The Energy Journal, vol. 1, no. 4, pp. 21-40. 
47. Khazzoom, J.D., M. Shelby, and R. Wolcott. 1990. "The Conflict Between Energy Conservation and Environmental Policy in the U.S. Transportation Sector," Energy Policy, vol. 5, pp. 456-458.

48. Kouris, G. 1983. "Fuel Consumption for Road Transport in the USA," Energy Economics, April, pp. 89-99.

49. Lancaster, K.J. 1970. "A New Approach to Consumer Theory," Ch. 2 in, The Demand for Travel: Theory and Measurement, R.E. Quandt, ed., D.C. Heath, Lexington, Mass.

50. Lave, C., 1996. "What Really Is the Growth of Vehicle Usage?" Transportation Research Record 1520, Transportation Research Board, Washington, DC.

51. Mabey, N. and J. Nixon. 1997. "Are Environmental Taxes a Free Lunch? Issues in Modeling the Macroeconomic Effects of Carbon Taxes," Energy Economics, vol. 19, no. 1, pp. 29-56.

52. Mannering, F. 1986. "A note on endogenous variables in household vehicle utilization equations", Transportation Research B, vol. 20, no. 1, pp. 1-6.

53. Mannering, F. 1983. "An Econometric Analysis of Vehicle Use in Multivehicle Households," Transportation Research A, vol. 17A, no. 3, pp. 183-189.

54. Mannering, F. and D.A. Hensher, 1987. "Discrete/continuous econometric models and their application to transport analysis", Transport Reviews, vol. 7, no. 3, pp. 227244.

55. Mannering, F. and C. Winston. 1985. "A Dynamic Empirical Analysis of Household Vehicle Ownership and Utilization," Rand Journal of Economics, vol. 16, no. 2, pp. 215-236.

56. Mayo, J.W. and J.E. Mathis. 1988. "The Effectiveness of Mandatory Fuel Efficiency Standards in Reducing the Demand for Gasoline," Applied Economics, no. 20, pp. 211-219.

57. McCarthy, P.S. 1996. "Market Price and Income Elasticities of New Vehicle Demands," The Review of Economics and Statistics, vol. 78, no. 3, pp. 543-547.

58. Murrell, D. 1980. Passenger Car Fuel Economy: EPA and Road, EPA 460/3-80010, Environmental Protection Agency, Motor Vehicle Emission Lab, Ann Arbor Michigan.

59. National Research Council. 1992. Aeronautical Technologies for the Twenty-First Century, National Academy Press, Washington, DC.

60. Nivola, P.S. and R.W. Crandall. 1995. The Extra Mile, The Brookings Institution, Washington, DC.

61. Oum, T.H., W.G. Waters II, and J.S. Yong. 1992. "Concepts of Price Elasticities of Transport Demand and Recent Empirical Estimates," Journal of Transport Economics and Policy, vol. 26, no. 2, pp. 139-154.

62. Pearce, D.W. and J.J. Warford. 1996. World without End, published for the World Bank by Oxford University Press, Cambridge.

63. Pickrell, D., 1994. "Description of VMT Forecasting Procedure for "Car Talk" Baseline Forecasts", manuscript, U.S. Department of Transportation, Volpe National Transportation Systems Center, Cambridge, Massachusetts. 
64. Porter, E.D. 1996. "U.S. Highway Fuel Demand: Trends and Prospects," Research Study \#084, American Petroleum Institute, Washington, DC.

65. Puller, S.L. and L.A. Greening. 1997. "A Decomposition of the Household Adjustment to Gasoline Price Change," in International Energy Markets: Competition and Policy, Proceedings of the $18^{\text {th }}$ Annual North American Conference of the international Association of Energy Economists, September 7-10, San Francisco.

66. Puller, S.L. and L.A. Greening. 1996. Household Adjustment to Gasoline Price: An Analysis Using Nine Years of U.S. Survey Data, No. LBNL-40015, Lawrence Berkeley National Laboratory, Berkeley, California.

67. Schipper, L.J., M.F. Figueroa, L. Price, and M. Espey. 1993. "Mind the Gap: The Vicious Circle of Measuring Automobile Use," Energy Policy, vol. 21, no. 12, pp. 1173-90.

68. Sterner, T. 1991. "Gasoline Demand in the OECD: Choice of Model and Data Set in Pooled Estimation," OPEC Review, vol. 15, no. 2, pp. 91-102.

69. Train, K. 1986. Qualitative Choice Analysis: Theory, Econometrics and Application to Automobile Demand, MT Press, Cambridge, Massachusetts.

70. U.S. Department of Commerce, Bureau of the Census. 1997. Statistical Abstract of the United States, $117^{\text {th }}$ edition, Washington, DC.

71. U.S. Department of Energy, Energy Information Administration, 1997. Annual Energy Review 1996, DOE/EIA-0384(96), Washington, DC.

72. U.S. Department of Energy, Energy Information Administration, 1997. Household Vehicles Energy Consumption 1994, DOE/EIA-0464(94), Washington, D.C., August.

73. U.S. Department of Energy, Energy Information Administration, 1985. Consumption Patterns of Household Vehicles 1983, DOE/EIA-0464(83), Washington, D.C., January.

74. U.S. Department of Energy, Energy Information Administration, 1983. Consumption Patterns of Household Vehicles, Supplement: January 1981 to September 1981, DOE/EIA-0328, Washington, D.C., February.

75. U.S. Department of Energy, Energy Information Administration, 1982. Consumption Patterns of Household Vehicles, June 1979 to December 1980, DOE/EIA-0319, Washington, D.C., April.

76. U.S. Department of Transportation, Volpe National Transportation Systems Center, 1994. Journey-to-Work Trends in the United States and its Major Metropolitan Area, 1960-1990, Cambridge, MA.

77. Varian, H.R. 1978. Microeconomic Analysis, W.W. Norton \& Co., New York.

78. Verlager, P.K. 1972. "Models of the Demand for Air Transportation," Bell Journal of Economics and Management Science, Autumn, pp. 437-457.

79. Walker, I.O. and F. Wirl. 1993. "Irreversible Price-Induced Efficiency Improvements: Theory and Empirical Application to Road Transportation," The Energy Journal, vol. 14, no. 4, pp. 183-205. 
80. Walls, M.A., A.J. Krupnick, and H.S. Hood. 1993. "Estimating the Demand for Vehicle-Miles Traveled Using Household Survey Data: Results from the 1990

Nationwide Personal Transportation Survey," Discussion Paper ENR 93-25, Energy and Natural Resources Division, Resources for the Future, Washington, DC.

81. Wheaton, W.C. 1982. "The Long-Run Structure of Transportation and Gasoline Demand," The Bell Journal of Economics, vol. 13, no. 2, pp. 439-454. 


\section{APPENDIX A}

\section{CONSTRUCTION OF THE RTECS DATA SETS}

The database used for this analysis was compiled from 1979-81, 1983, 1985, 1988, 1991, and 1994 Residential Transportation Energy Consumption Survey (RTECS) data produced by the U.S. Department of Energy (USDOE) Energy Information Administration (EIA). ${ }^{11}$ Due to variations in content and format among these data sets, each data set was processed separately before being combined into multi-year databases. Each database was constructed based on the number of vehicles for which data was available for each household. This process was accomplished as follows:

- Relevant data items from each survey were compiled into a single database. The formats of the survey databases differ as did the codes used for several variables. Both formats and coding conventions were modified to be as consistent as possible. The assumptions and methods used to make the data consistent are explained more fully in the individual data descriptions.

- All records in the unified database were transposed so that each record represented a single vehicle with associated vehicle and household characteristics.

- A unique identification number was assigned to each household and vehicle. Household numbers are based on the survey year and the household identification number used in that survey. Vehicle identification numbers were formed from the survey year, household ID number, and the vehicle number assigned by the respondent.

- For all surveys, except the 1979-81 surveys, all vehicle records that did not have annual mileage data were deleted. The 1979-81 survey was conducted on a monthly basis, with households only reporting for a few months out of the year. For this data, only those records with an odometer reading for the first month and the last month the household was in the survey were used. Furthermore, the first and last month had to cover an eight-month time period. Annual mileage was then extrapolated for the remaining months using an equation provided by EIA (this methodology is described later in the document). The 1979-81 mileages were then adjusted to "1980-equivalent" mileages (this method is also described later).

"The data from the 1979-1981 monthly surveys was combined to form a single " 1980 " survey. 
- For 1979-81, average annual MPG was estimated by dividing the sum of the mileages by the sum of the gallons consumed for all months the household was in the survey.

- The annual fuel consumed by each vehicle in the 1979-81 survey was calculated by dividing the 1980-equivalent mileage by the average MPG.

- The average number of vehicles in each household was estimated for the 1979-80 survey by averaging the number of eligible vehicles (NELIGVEHS) for all months that the household was in the survey.

- Variable codes that were not uniform across all surveys were converted to a uniform format. This includes the codes for fuel type, leaded/unleaded fuel, fuel grade, vehicle type, income level, census region, and urban/rural designation.

- The annual average fuel price in 1994 cents per gallon for "All Fuel Types" for each survey year as calculated based on EIA data and deflated using the CPI-U from the Bureau of Labor Statistics (field EIAPRICE) was added to the database.

- A field was added to the database indicating the consumer price index for all urban consumers for the survey year, indexed to $1994=100$ (field CPI_U).

- For each vehicle within a household, a field was added specifying the fleet average fuel efficiency of all new vehicles of the vehicle's type (car vs. truck) and model year (fields CAFE01, CAFE02,...). This variable is not the federal fuel economy standard for the year in which the vehicle was sold. It is the average fuel economy of all vehicles sold in that model year.

- Twelve fields were added containing the EIA estimated average annual fuel prices for the twelve years preceding the survey year (fields EIAP1 through EIAP12; EIAP1 being the first year prior).

- The unified database was then divided into five separate databases for 1-vehicle households, 2-vehicle households, 3-vehicle households, 4-vehicle households, and 5-or-more-vehicle households. Each record contains the household data and the data for all vehicles in that household. Multiple records for each household were included, so that each vehicle appears once and only once in each position. Thus, a 3-vehicle household would have three records in which a different vehicle was the first, second, and third vehicle in each. In the first record, vehicles would be arranged $1,2,3$, in the second $2,3,1$, and in the third 3,1,2.

- Several individual households were deleted because they had questionable data that caused a numerical overflow in data processing (households 2392 and 4791 in 
the 1979 survey; $1707,2174,2577,3408,4414,4524$, and 4760 in the 1980 survey; 2107 in the 1981 survey) or had more than one vehicle within the household with the same vehicle ID number (households 1514, 1573, and 2328 in the 1983 survey).

- A uniformly distributed random number was assigned to each record in each database (field RANDNO).

- A uniformly distributed random number was assigned to each household in each database (field RANDNOHH).

\section{FIELD DEFINITIONS}

The following paragraphs provide a brief guide to the variables (fields) within the compiled data sets. These field definitions are based on the EIA documentation provided with the data sets which in many cases is minimal. Also, not all of these fields are used in this analysis. Some are available for only a few surveys, and others were used only to calculate or code values for other variables/fields. Field names that pertain to individual vehicle data end in a two-digit number, that varies with the vehicle's number within the record. For example, in a three-vehicle household, the model year of the first vehicle in the record will be YEAR01, the model year for the second would be contained in YEAR02, and the third in YEAR03.

SURVYEAR: Calendar year of the survey. The 1983-94 data sets contain annual data. The 1979-81 data set, however, contains monthly data. Households were included in the survey for two consecutive months, left out for the following four months, and surveyed again during the next two months. Thus, there is monthly data for four months. These data items were annualized to be compatible with the 12 month data available in the other surveys. Also, since the data collection schedule for 1979-81 did not always begin on Jan. 1 of each year (i.e., households were polled on a "rolling" schedule), all data has been scaled to 1980. Thus, SURVYEAR for all 1979-81 data is given as 1980.

ORIGSURVYR: This is provided to show the original starting year of each household in the 1979-81 survey. This field was used to adjust 1979-81 travel data to 1980 .

VEHID01: Vehicle ID code that uniquely identifies each vehicle. The first two characters indicate the survey year; the next four indicate the household ID number; the last two indicate the vehicle number within the household as given by the survey respondent. Note: For 1979-81 data, the first two numbers indicate the survey in which the household participated (11=NIECS, 12=SCREENER, 13=RECS1) rather than the year. 
TYPE01: Vehicle type as coded in the original survey data. However, since vehicle type categories are not consistent across all surveys, vehicle types have been re-coded consistent with one another in field TYPE01b.

TYPE01b: This is a re-code of TYPE01 to make items as consistent as possible across surveys. $1=$ station wagon, $2=$ standard passenger car, $3=$ sport utility, $4=\mathrm{mini} /$ passenger van, $5=$ large/cargo van, $6=$ pickup truck, $21=$ other, other truck, motor home, $99=$ no answer, not applicable, don't know. See Table A1.

Table Al. Vehicle Type Conversions

\begin{tabular}{ccc}
\hline Survey Year & Original Value & New Value \\
\hline $1980,1983,1985$ & 7,8 & 21 \\
\hline 1988,1991 & 1 & 2 \\
2 & 2 \\
3 & 1 \\
4 & 5 \\
5 & 4 \\
-1 & 3 \\
\hline 1994 & 1 & 2 \\
& 2 & 1 \\
3 & 5 \\
& 5 & 6 \\
6 & 3 \\
\hline
\end{tabular}

YEAR01: Last two digits of the vehicle model year.

CYLS01: Indicates the number of cylinders in the vehicle's engine. All values between 2 and 8 (inclusive) refer to the number of cylinders; 9=rotary; 21=other (including 12 cylinder engines); $96-98$ means don't know, refused to answer, etc. (i.e., no data). Data is missing for vehicles in survey 12 (i.e., 1980 data). Data is available for surveys 11 and 13 (i.e., 1979 and 81 data) and for all surveys from 1983 to 1994.

JOBUSE01: Indicates whether or not the vehicle is used for work ( $0=$ no, $1=y e s, 6=$ don't know, $7=$-refused, $8=$ no answer, $9=$ not applicable). (CAUTION: The actual questions asked in the various surveys differ somewhat. Thus, the effect of these differences on the usefulness of this data item is unknown.)

DRIVES01: Indicates the number of drivers for the vehicle. Not available in 1979-81, 1988, 1991, and 1994 RTECS. 
DAYS01: The number of days the household had the vehicle during the year. Not available for 1979-81 data.

MPG01: Fuel efficiency estimate for the vehicle (tenths of miles). For 1983 and 1985, calculated as total miles driven divided by total gallons consumed. For 1988 and 1991, on-road in-use adjusted MPG is used. For 1979-81, average annual MPG was estimated by dividing the sum of the mileages by the sum of the gallons consumed for all months the household was in the survey.

GALS01: Gallons of fuel consumed by the vehicle. For 1979-81 data, this was calculated as MILES01/MPG01.

CAFE01: Sales weighted average fuel efficiency for cars or light trucks (as appropriate) of the same model year of the vehicle in question. CAFE is assigned for each vehicle based on model year and vehicle type. Vehicle types (TYPE01b)1-5 are assigned fuel efficiencies for autos; type 6 and 21 vehicles are assigned truck efficiencies. If the vehicle's model year and/or type is unknown, CAFE01 is assigned a value of 99. Truck fuel efficiency averages are taken from a technical report prepared for EPA by Heavenrich and Hellman (Heavenrich, R. M., and Hellman, K. H. 1996. Light-Duty Automotive Technology and Fuel Economy Trends Through 1996. Technical Report EPA/AA/TDSG/96-01. August). Passenger car fuel efficiency averages are productionweighted data from manufacturer's fuel economy reports given in U.S. Department of Transportation (USDOT) National Highway Traffic Safety Administration (NHTSA) data provided by Orron Kee on November 17, 1997. See Table A2.

Table A2. Values Used for Fleet Average Fuel Economy, Average Fuel Price, and Consumer Price Index

\begin{tabular}{|c|c|c|c|c|}
\hline \multirow[b]{2}{*}{ Year } & \multicolumn{2}{|c|}{ Fleet Average Fuel Economy } & \multirow{2}{*}{$\begin{array}{c}\text { EIA Avg. Fuel } \\
\text { Price, All Types } \\
(1994 \not)\end{array}$} & \multirow{2}{*}{$\begin{array}{c}\text { CPI-U } \\
(1994=100)\end{array}$} \\
\hline & Passenger Car & Trucks & & \\
\hline $1955-61$ & 16.1 & 13.7 & $-\cdots$ & --- \\
\hline $1962-63$ & 16.0 & 13.7 & -- & $\ldots$ \\
\hline $1964-65$ & 15.9 & 13.7 & -- & $-\cdots$ \\
\hline 1966 & 15.6 & 13.7 & -- & --- \\
\hline 1967 & 15.3 & 13.7 & 153 & 22.5 \\
\hline 1968 & 15.0 & 13.7 & 149 & 23.5 \\
\hline 1969 & 15.1 & 13.7 & 146 & 24.7 \\
\hline 1970 & 15.2 & 13.7 & 142 & 26.2 \\
\hline 1971 & 14.7 & 13.7 & 139 & 27.3 \\
\hline 1972 & 14.8 & 13.7 & 133 & 28.2 \\
\hline
\end{tabular}




\begin{tabular}{|c|c|c|c|c|}
\hline \multirow[b]{3}{*}{ Year } & \multicolumn{4}{|c|}{ ElA Avg. Fuel } \\
\hline & \multicolumn{2}{|c|}{ Fleet Average Fuel Economy } & \multirow{2}{*}{$\begin{array}{l}\text { Price, All Types } \\
(1994 \not)\end{array}$} & \multirow{2}{*}{$\begin{array}{c}\text { CPI-U } \\
(1994=100)\end{array}$} \\
\hline & Passenger Car & Trucks & & \\
\hline 1973 & 13.0 & 13.7 & 135 & 30.0 \\
\hline 1974 & 13.6 & 13.7 & 166 & 33.3 \\
\hline 1975 & 15.9 & 13.7 & 163 & 36.3 \\
\hline 1976 & 17.3 & 14.4 & 156 & 38.4 \\
\hline 1977 & 18.8 & 15.6 & 156 & 40.9 \\
\hline 1978 & 19.9 & 15.2 & 148 & 44.0 \\
\hline 1979 & 20.3 & 14.7 & 180 & 49.0 \\
\hline 1980 & 24.3 & 18.6 & 220 & 55.6 \\
\hline 1981 & 25.9 & 20.1 & 221 & 61.4 \\
\hline 1982 & 26.6 & 20.5 & 197 & 65.1 \\
\hline 1983 & 26.4 & 20.9 & 182 & 67.2 \\
\hline 1984 & 26.9 & 20.5 & 171 & 70.1 \\
\hline 1985 & 27.6 & 20.6 & 165 & 72.6 \\
\hline 1986 & 28.2 & 21.4 & 126 & 74.0 \\
\hline 1987 & 28.5 & 21.6 & 125 & 76.7 \\
\hline 1988 & 28.8 & 21.2 & 121 & 79.8 \\
\hline 1989 & 28.4 & 20.9 & 127 & 83.6 \\
\hline 1990 & 28.0 & 20.7 & 138 & 88.2 \\
\hline 1991 & 28.4 & 21.3 & 130 & 91.9 \\
\hline 1992 & 27.9 & 20.8 & 126 & 94.7 \\
\hline 1993 & 28.4 & 21.0 & 117 & 97.5 \\
\hline 1994 & 28.3 & 20.8 & 112 & 100.0 \\
\hline 1995 & 28.6 & 20.4 & --- & --- \\
\hline
\end{tabular}

MILES01: Total miles traveled by the vehicle. For 1979-81, annual totals were calculated based on odometer readings for the first and last month each vehicle was in the survey (i.e., an 8-month span). Regression equations and coefficients provided by EIA were used to estimate annual totals based on 8 -month data. Two equations were provided. For this analysis, both were used and the average mileage produced from the two equations was used.

\footnotetext{
Annual Mileage ${ }_{a}=117+(1.434 \times$ Eight Month Mileage $)$

Annual Mileage $_{b}=49+(1.413 \times$ Eight Month Mileage $)$

Annual Mileage $_{(a v g)}=\left(\right.$ Annual Mileage ${ }_{a}+$ Annual Mileage $\left._{b}\right)$
} 
These estimates were then scaled to 1980-equivalent miles traveled using the following equation.

$$
1980 \text { Equivalent Mileage }=\text { Annual Mileage }{ }_{v, t} \times \frac{A v g \text { Annual Mileage }{ }_{\text {Janso }}}{\text { Avg Annual Mileage }{ }_{t}}
$$

where

Annual Mileage $e_{v, \mathrm{t}}=$ annual mileage of vehicle $v$ in eight-month time period $t$ (this is the mileage estimate used in MILES01)

Avg Annual Mileage $_{J_{\text {an80 }}}=\quad$ estimated average annual mileage of all vehicles in the eight-month time period beginning in January 1980 Avg Annual Mileage ${ }_{t}=\quad$ estimated average annual mileage of all vehicles in eightmonth time period $t$.

ACOST01: Average cost/gallon for vehicle fuel (tenths of current-value cents). For 1979-81 data, the sum of the monthly fuel cost for the vehicle is divided by the sum of the gallons purchased for each vehicle for all months the household was in the survey.

EIAPRICE: The annual average fuel price (in 1994 pennies) per gallon for All Fuel Types as calculated based on EIA data and deflated using deflated by the CPI-U from the Bureau of Labor Statistics. See Table A2.

EIAP1 through EIAP12: EIA estimated average annual fuel prices for the 12 years preceding the survey year. EIAP1 is the first year prior to the survey year while EIAP12 reflects the price 12 years prior to the survey year. All of these prices are in 1994 pennies, deflated by the CPI-U from the Bureau of Labor Statistics. See Table A2.

CPI_U: Consumer price index (all urban consumers) for the survey year (1994=100). See Table A2.

FTYPE01: Fuel type for the vehicle. Some categories were re-coded for consistency among surveys (1=gasoline, $2=$ diesel, $3=$ gasohol, $4=$ propane, $9=$ not applicable). See Table A3.

FLEAD01: Indicates whether or not leaded fuel was used in the vehicle. Some categories were re-coded for consistency among surveys ( 1 =leaded, $2=$ unleaded, $3=$ don't know, 9=not applicable). See Table A3. 
Table A3. Fuel Type Conversions

\begin{tabular}{|c|c|c|c|c|c|}
\hline \multirow[b]{2}{*}{ Survey } & \multirow{2}{*}{$\begin{array}{c}\text { Original } \\
\text { Variable/Field }\end{array}$} & \multirow[b]{2}{*}{ Original Value } & \multicolumn{3}{|c|}{ New Value } \\
\hline & & & FTYPE01 & FLEAD01 & FGRADE01 \\
\hline \multirow[t]{9}{*}{1980} & FUELASKD & 01 & 1 & 2 & 1 \\
\hline & & 02 & 1 & 2 & 2 \\
\hline & & 03 & 1 & 1 & 1 \\
\hline & & 04 & 1 & 1 & 2 \\
\hline & & 05 & 2 & 9 & 9 \\
\hline & & 07 & 3 & 9 & 9 \\
\hline & & 21 & 5 & 3 & 3 \\
\hline & & 96 & 8 & 3 & 3 \\
\hline & & 99 & 9 & 9 & 9 \\
\hline \multirow[t]{2}{*}{1983} & FLEAD01 & 3 & & 9 & \\
\hline & FGRADE01 & 3 & & & 9 \\
\hline \multirow[t]{2}{*}{1985} & FLEAD01 & 3 & & 9 & \\
\hline & FGRADE01 & 3 & & & 9 \\
\hline \multirow[t]{7}{*}{1994} & FUEL01 & $01,02,03,10$ & 1 & 2 & \\
\hline & & 04 & 1 & 1 & \\
\hline & & 05 & 3 & 9 & \\
\hline & & 07 & 4 & 9 & \\
\hline & & 09 & 2 & 9 & \\
\hline & & 06,08 & 5 & 9 & \\
\hline & & 99 & 9 & 9 & \\
\hline
\end{tabular}

FGRADE01: Indicates the grade of fuel used in the vehicle. Some categories were re-coded for consistency among surveys (1=regular, $2=$ =remium, $3=$ intermediate/mid-grade, $4=$ reg. and prem. equally, $5=$ other, $9=$ not applicable). See Table A3.

HHID: Household ID number (unique to each household). First two digits indicate the survey year (or survey, 1979-81), last four indicate the number code within each survey.

REGIONC: Census region (part of country) in which household is located. 1=northeast, $2=$ north central, $3=$ south, $4=$ west.

AREA1980: Indicates the rural/urban location classification for the household as classified by either the 1970,1980 , or 1990 Census. Note that the urban/rural classification for 1994 is different in meaning than those for the other surveys. Thus, 
categories had to be re-coded to make them as consistent as possible over all surveys. See NEWAERA below.

NEWAREA: Area re-coded to make all surveys as consistent as possible ( $1=$ inside central city, $2=$ outside central city). Note there are still incompatibility problems between 1994 data and other survey years. See Table A4.

Table A4. Household Area Conversions

\begin{tabular}{lccc}
\hline \multicolumn{1}{c}{ Survey Year } & Original Variable Name & Original Value & New Value \\
\hline 1980 & AREA1970 & $3,4,5$ & 2 \\
$1983,1985,1988,1991$ & AREA1980 & 4 & 2 \\
1994 & URBRUR & 3,4 & 2 \\
\hline
\end{tabular}

NDRIVERS: Number of drivers in household.

INCOME: Total income of entire household (income categories). The categories are not compatible across surveys. DO NOT USE THIS FIELD; USE INCOME2 INSTEAD.

INCOME2: This is a re-code of INCOME. RTECS only indicates income intervals, rather than dollar amounts. Thus, these intervals were converted to (current) dollar amounts by taking the midpoint value of each interval in each survey. However, for the categories with out a maximum bound, an "average" value was estimated based on data in annual editions of Statistical Abstract of the United States. The values used for the highest income groups by year are as follows: $1980=\$ 61,000 ; 1983=\$ 48,000$; $1985=\$ 50,000 ; 1988=\$ 102,000 ; 1991=\$ 106,000 ; 1994=\$ 125,000$.

NHSLDMEM: Number of members in the household.

AVGVEHS: Average number of vehicles (in hundredths) owned by the household during the year. Due to vehicles dropping in and out of the survey, as well as incomplete records for many households, this often will not match the number of vehicles for which data is given. For 1985, 1988, 1991, and 1994, the average number of vehicles is given in a field in each data set. EIA calculated this value by averaging the number of vehicles in the household during the year weighted by the number of days each vehicle was in the household during that year. For 1983, this variable was calculated by ORNL using the same method. For 1979-81, households are only surveyed for a couple of months out of the year, so this method cannot be used. ORNL averaged the number of eligible vehicles in each household for all months in which the household was in the survey (NELIGVEH). 
RANDNO: This is a uniformly distributed random number assigned to each record (i.e., vehicle).

RANDNOHH: This is a uniformly distributed random number assigned to each household.

SURVEYNO: Only used with 1979-81 data. Indicates the survey in which the household/vehicle participated (11=NIECS, 12=SCREENER, 13=RECS1). Not used in the analysis.

\section{DATABASE VARIABLE NAME RELATIONSHIPS}

The variables found in the RTECS are not uniform among surveys. The following table is provided to identify the field in each RTECS database which corresponds to each variable (or field) in the multi-survey database. 
Table A5. Guide to Variables Used in Each Original RTECS Database and the Constructed Multi-Survey Databases.

\begin{tabular}{|c|c|c|c|c|c|c|}
\hline \multirow{2}{*}{$\begin{array}{c}\text { Variable } \\
\text { Name }\end{array}$} & \multicolumn{6}{|c|}{ Field Name in Original Database } \\
\hline & $1979-81$ & 1983 & 1985 & 1988 & 1991 & 1994 \\
\hline TYPE01 & KVEHTYP* & TYPE01* & TYPE01* & TYPE01* & TYPE01* & TYPEO1* \\
\hline YEAR01 & YRVMODEI & YEAR0I & YEARO1 & YEAR01 & YEAR01 & YEAR01 \\
\hline CYLSO1 & KENGTYV & CYLSO1 & CYLSOI & CYLSO1 & CYLSO1 & CYLSOI \\
\hline JOBUSE01 & KUJBWYV & JOBUSE01 & JOBUSE01 & JOBUSE01 & FJOBUSE01 & FСОМUTO1 \\
\hline DRIVES01 & No Data & DRIVES01 & DRIVES01 & No Data & No Data & No Data \\
\hline DAYS01 & No Data & DAYSO1 & DAYSO1 & DAYSO1 & DAYS01 & DAYS01 \\
\hline MPG01 & Calc'd & MPGOI & MPG01 & MPGADJOI & MPGADJO1 & MPGADJ01 \\
\hline GALSO1 & Calc'd & GALSO1 & GALSOI & GALSO1 & GALSO1 & GALSO1 \\
\hline MILESOI & Cale'd & MILES01 & MILESOI & MILESOI & MIIES01 & MILESOI \\
\hline ACOST01 & Calc'd & ACOST01 & ACOST01 & ACOST01 & ACOSTOI & ACOST0I \\
\hline FTYPE01 & FUELASKD* & FTYPE01* & FTYPE01* & ETYPE $01 *$ & ETYPEOI* & FUEL01* \\
\hline FLEADO1 & FUELASKD* & FLEADOI * & FLEADO 1* & FLEAD01* & FLEADO 1* & FUEL01* \\
\hline FGRADE01 & FUELASKD* & FGRADE 01* & FGRADE01* & FGRADE01* & FGRADE01* & GRADE01 * \\
\hline REGIONC & REGIONC* & REGIONC & REGIONC & REGIONC & REGIONC & REGIONC \\
\hline AREA1980* & AREA1970 & AREA1980 & AREA1980 & AREA1980 & AREA1980 & URBRUR \\
\hline NDRIVERS & NDRIVERS & NDRIVERS & NDRIVERS & NDRIVERS & DRTVEMON & DRIVEMON \\
\hline INCOME* & KINCOMEI & INCOME83 & INCOME85 & MONEYPY & MONEYPY & MONEYPY \\
\hline NHSLDMEM & NHSLDMEM & NHSIDMEM & NHSLDMEM & NHSIDMEM & NHSLDMEM & NHSLDMEM \\
\hline AVGVHES & Calc'd & AVGVEHS & AVGVEHS & AVGVEHS & AVGVEHS & AVGVEHS \\
\hline
\end{tabular}

$\mathrm{ND}=$ No data available for survey year.

*=Data re-coded. For AREA1980 and INCOME, re-coded data is contained in the fields NEWAREA and INCOME2, respectively. 


\section{INTERNAL DISTRIBUTION}

1. M. S. Bronzini

2. G. E. Courville

3. T. R. Curlee

4-8. R. C. Gibson

9-38. D. L. Greene

39-43. J. R. Kahn

44. C. I. Moser

45. R. B. Shelton

46. ORNL Patent Office

47-49. Central Research Library

50. Document Reference Section

51-53. Laboratory Records

54. Laboratory Records-RC

\section{EXTERNAL DISTRIBUTION}

55. L. A. Abron, President, PEER Consultants, P.C., 1460 Gulf Blvd., $11^{\text {th }}$ Floor, Clearwater, Florida 34630

56. Steve Bernow, Tellus Institute, 11 Arlington Street, Boston, MA 02116-3411

57. John Berg, Federal Highway Administration, HPP-13, Office of Policy Development, 400 Seventh Street, S.W., Washington, DC 20590

58. David Chien, Energy Information Administration, Room 2F-081, U.S. Department of Energy, 1000 Independence Avenue, S.W., Washington, DC 20585

59. John DeCicco, American Council for an Energy-Efficient Economy, 1001 Connecticut Avenue, N.W., Suite 801, Washington, DC 20036

60. Carmen Difiglio, U. S. Department of Energy, PO-62, Room 7H-063, Forrestal Building, 1000 Independence Avenue, S.W., Washington, DC 20585

61. T. E. Drabek, Professor, Department of Sociology, University of Denver, Denver, Colorado 80208-0209

62. Lorna Greening, Hagler-Bailly Services, P.O. Drawer O, 1881 Ninth Street, Suite 201, Boulder, $\mathrm{CO} 80302$

63. Howard K. Gruenspecht, U.S. Department of Energy, Office of Economic, Electricity, and Natural Gas Analysis, PO-61, 1000 Independence Avenue, S.W., Washington, DC 20585-0106

64. S. G. Hildebrand, Director, Environmental Sciences Division, Oak Ridge National Laboratory, Post Office Box 2008, Oak Ridge, Tennessee 37831-6037

65. Skip Laitner, EPA Office of Atmospheric Programs, 501 3rd Street, N.W., 4th Floor, MS-6201J, Washington, DC 20001

66. John Lawson, Ministry of Transportation, 1201 Wilson Avenue, Downsview, Canada M3M IJ8 
67. Barry McNutt, U. S. Department of Energy, P0-62, Room 7H-021, Forrestal Building, 1000 Independence Avenue, S.W., Washington, DC 20585

68. Phil Patterson, U. S. Department of Energy, CE-30, Forrestal Building, 1000 Independence Avenue, S.W., Washington, DC 20585

69. Don H. Pickrell, Volpe Transportation Systems Center, U.S. Department of Transportation, DTS-40 Kendall Square, Cambridge, MA 02142

70. Peter Reilly-Roe, Energy, Mines and Resources Canada, Technology \& Policy Analysis Transportation Energy Division, 580 Booth Street, Ottawa, Ontario, Canada K1A OE4

71. P. R. Rittelmann, FAIA, Executive Vice President, Burt Hill Kosar Rittelmann Associates, 400 Morgan Center, Butler, Pennsylvania 16001-5977

72. Danilo J. Santini, Argonne National Laboratory, Center for Transportation Research, 9700 South Cass Avenue, ES/362 2B, Argonne, IL 60439-4815

73. Lee Schipper, International Energy Agency, Office of Long-Term Cooperation and Policy Analysis, 2, rue Andre Pascal, 75775 Paris Cedex 16, France

74. S. F. Tierney, The Economic Resource Group, Inc., One Mifflin Place, Cambridge, Massachusetts 02138

75. Margaret Walls, Resources for the Future, Energy and Natural Resources Division, 1616 P Street, N.W., Washington, DC 20036

76. C. M. Walton, Ernest H. Cockrell Centennial Chair in Engineering and Chairman, Department of Civil Engineering, University of Texas at Austin,E Cockrell, Jr. Hall I, Suite 4210, Austin, Texas 78712-1075

77. Mary Beth Zimmerman, U.S. Department of Energy, PO-62, Room 7H-075, 1000 Independence Avenue, S.W., Washington, DC 20585

78-87. OSTI, U.S. Department of Energy, P.O. Box 62, Oak Ridge, Tennessee 37831 